is report was prepared as an account of work sponsored by an agency of the United States vernment. Neither the United States Government nor any agency thereof, nor any of their iployees, makes any warranty, express or implied, or assumes any legal liability or responsiity for the accuracy, completeness, or usefulness of any information, apparatus, product, or ocess disclosed, or represents that its use would not infringe privately owned rights. Referce herein to any specific commercial product, process, or service by trade name, trademark, inufacturer, or otherwise does not necessarily constitute or imply its endorsement, recomindation, or favoring by the United States Government or any agency thereof. The views d opinions of authors expressed herein do not necessarily state or reflect those of the lited States Government or any agency thereof.
ONWI-449

Distribution Category UC-70

\title{
Some Characteristics of Potential Backfill Materials
}

\author{
Technical Report
}

May 1983

Dale R. Simpson

\author{
Lehigh University \\ Bethlehem, PA 18015
}

The content of this report was effective as of October 1982. This report was prepared by Lehigh University under Subcontract E512-07800 with Battelle Project Management Division, Office of Nuclear Waste Isolation under Contract No. DE-AC06-76RLO1830 and DE-AC02-83CH10140 with the U.S. Department of Energy. This contract was administered by the Battelle Office of Nuclear Waste Isolation. 


\section{DISCLAIMER}

This report was prepared as an account of work sponsored by an agency of the United States Government. Neither the United States Government nor any agency Thereof, nor any of their employees, makes any warranty, express or implied, or assumes any legal liability or responsibility for the accuracy, completeness, or usefulness of any information, apparatus, product, or process disclosed, or represents that its use would not infringe privately owned rights. Reference herein to any specific commercial product, process, or service by trade name, trademark, manufacturer, or otherwise does not necessarily constitute or imply its endorsement, recommendation, or favoring by the United States Government or any agency thereof. The views and opinions of authors expressed herein do not necessarily state or reflect those of the United States Government or any agency thereof. 


\section{DISCLAIMER}

Portions of this document may be illegible in electronic image products. Images are produced from the best available original document. 
ABSTRACT

A backfill material is one of the multiple barriers that may be involved in the disposal of nuclear waste. Such backfill should be a desiccant with the hydrous product having acceptable stability; it should sorb any released radiolsotopes, and it should reseal any breached site. The backfill must also have acceptable thermal conductivity.

This report presents data on the rate of hydration and the nature of the product of reaction of some candidate backfil1 materials with water and with brine. Thermal conductivity data is reported for both the reactants and the products.

Granular MgO at $150 \mathrm{C}$ completely hydrates in less than 10 hours. At $60 \mathrm{C}$ and $20 \mathrm{C}$, such extensive hydration requires about 100 and 1000 hours, respectively. The product of the reaction is stable to more than $300 \mathrm{c}$.

A doped dicalcium silicate was less reactive and the product contains less water of crystallization than the Mgo. The reaction product of dicalcium silicate is cementous, but it has low thermal stability.

Bentonite readily reacts with water and expands. The hydrous product has very low thermal stability with the water lost continuously in the range of 20 to $105 \mathrm{C}$. Thus, this low-temperature desiccant becomes a water source with even a slight increase in temperature. Bentonite reacts with an NBT-6a type brine. The reaction product has the properties of vermiculite, which Indicates that magnesium ions have diffused into the bentonite structure ard are not simply adsorbed on the surface. If bentonite is emplaced in a saline environment, the properties of vermiculite, the reaction product, should also be considered. 
The thermal conductivity of MgO, dicalcium silicate, and bentonite is primarily dependent on the porosity of the sample. With a range of porosity of 36 to 56 percent, thermal conductivity values of 0.22 to $1.02 \times 10^{-3}$ $\mathrm{cal} / \mathrm{cm} . \mathrm{sec}^{\circ}$ were determined. Thermal conductivity values increased with increased hydration of the samples. The samples were jacketed for the determinations. A slight increase in thermal conductivity was found with increased temperature, in contrast to most rocks. This may result from the jacketed samples getting a better grain-to-grain contact with increased temperature.

If the conductive data for the different materials is equated to the same porosity, Mgo has the superior thermal conductivity compared to bentonite or dicalcium silicate. Porosity is an extrinsic variable controlled by grain size and installation techniques. In practice, the thermal conductivity can be improved by installing anhydrous material which then is subjected to a partial or complete in situ hydration. Since the hydrous product has a larger volume, such controlled hydration would reduce the porosity. 
TABLE OF CONTENTS

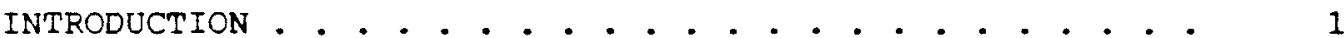
SCOPE ............................. . . . . . . 3

HYDRATION STUDIES . . . . . . . . . . . . . . . . . . . . . . . 4

Hydration of MgO . . . . . . . . . . . . . 4 Background . . . . . . . . . . . . . 44 Procedure . . . . . . . . . . . . . 5

Results.................. . . . . 6

Hyaration of Variants of $\mathrm{Ca}_{2} \mathrm{SiO}_{4}$. . . . . . . . 9 Background ...... . . . . . . . . 9 Procedure .. . . . . . . . . . . 10 Results................... . . . 11

Hydration of Bentonite . . . . . . . . . . 14 Background . . . . . . . . . . . . 14 Procedure . . . . . . . . . . . . . . 15 Results . . . . . . . . . . . . . 15

Hydration with Low Vapor Pressure . . . . . 17

REACTION OF BENTONITE WITH BRINE . . • . . . . . . . . . . . 18

Background . . . . . . . . . . . . 18

Procedure .. . . . . . . . . . . . . 20

Results .................... . . . 21

Sumary . . . . . . . . . . . . . . . 25

THERMAL CONDUCTIVITY MEASUREMENTS • . . . . . • . . . . . . 28

Background . . . . . . . . . . . . . . 28

Procedure . . . . . . . . . . . . . . 32

Samples . . . . . . . . . . . . . . . 34

Results . . . . . . . . . . . . . . 36

Thermal Conductivity Values . . . . . . . . 40

Conclusions . . . . . . . . . . . . . . 40

SUMMARY AND CONCLUSIONS . . . . . . . . . . . . . . . . . . 45

REFERENCES . . . . . . . . . . . . . . . . . . . . . . . 49 
Hydration of Mgo as a function of grain size.

Hydration of doped $\mathrm{Ca}_{2} \mathrm{SiO}_{4}$ as a function of grain size.

4 Basal spacing of bentonite and its reaction products.

SEM of bentonite before and after reaction in

Thermal conductivity as a function of porosity of sandstones.

7 Thermal diffusivity as a function of temperature for $\mathrm{MgO}$ and $\mathrm{MgO}+\mathrm{Mg}(\mathrm{OH})_{2}$.

Thermal diffusivity as a function of temperature for doped $\mathrm{Ca}_{2} \mathrm{SiO}_{4}$ and doped $\mathrm{Ca}_{2} \mathrm{SiO}_{4}$ with water as
a separate phase.

9 Thermal diffusivity as a function of temperature for bentonite of different bulk densities.

10 Thermal diffusivity as a function of temperature for bentonite + water.

11 Thermal conductivity of candidate overpack materials as a function of porosity. 
, 


\section{List of Tables}

Table

Page

1 x-ray diffraction data for bentonite.

2

Representative formulas of montmorillonite and vermiculite.

3 x-ray diffraction data of bentonite and reaction products.

4

DTA and weight loss data for bentonite and its reaction products. 


\subsection{INTRODUCTION}

The disposal of nuclear waste in a geologic setting involves the multiple barrier concept. A backfill material around the waste canisters may be one of the barriers. Ideally, the backfill material should serve as a long-term desiccant for the system and have appropriate thermal conductivity. If a catastrophic or accidental breaching of the system should occur, the ideal backfill should restore the integrity of the system, seal openings, and sorb and confine the contaminants.

Earlier research was aimed at screening candidate materials for potential use as backfill for radioactive waste stored in salt beds. A number of materials were identified, and subsequent experiments showed them to be suitable and effective for such a role in a salt environment.

The chemical variants of dicalcium silicate were also studied to determine their suitability as backfill materials. Dicalcium silicate is a principal constituent of portland cement. It is known to hydrate to a compound with an enormous surface area, tobermorite, and yet have a set strength that would reestablish the integrity of a breached system. This "cementing" material was doped with $\mathrm{CaNaPO}_{4}$ to stabilize some desirable phases and introduce phosphate into the system. CaNaPO $_{4}$ dissociates in water forming apatite and a basic solution. Apatite is the mineral of teeth, bone, and phosphorite deposits, and it is a scavenger used for filtering and ion exchange.

The sodium phosphate-bearing variant of dicalcium silicate hydrates to apatite and torbermorite. These hydration products have a large surface area, some desirable ion exchange properties, and a set strength. The research was directed at establishing the phase relations of the binary 
system CaNaPO $4{ }_{4}-\mathrm{Ca}_{2} \mathrm{SiO}_{4}$ at high temperatures. From these relations the best compositions were selected for hydration studies. These hydration studies were at $20 \mathrm{C}$ and one atmosphere. The stability of the hydration product was established by differential thermal analysis and thermogravimetric analysis. Some feasibility experiments bearing on the hydration were conducted at elevated temperature and pressure.

Bentonite has recelved considerable attention as a backfill material. It readily sorbs water and cations, and it expands with hydration. Bentonite was not considered an ideal backfill material in this study because with heating, to even less than $100 \mathrm{C}$, some interlayer water 1 s lost with partial collapse of the expanded form. With this release of the interlayer water, the fate of sorbed lons is unknown. Other problems with bentonite powder are its low density, its difficulty in packing, and its plasticity, especially when wet. For salt repositories, the behavior of bentonite in a brine is a concern. For example, some brines have a high percentage of calcium and magnesium ions that may exchange with the sodium in bentonite, ylelding a calcium or magnesium-bearing bentonite. Unfortunately, the calcium bentonites lack the high expansion and sorptive capacity of the sodium bentonites. In addition, bentonites, with their extremely large surface area, may recrystallize to a more stable compound with reduced surface area. Brines are known to be potent mineralizers. 


\subsection{SCOPE}

This report presents further research results on MgO and chemical variants of $\mathrm{Ca}_{2} \mathrm{SiO}_{4}$. Both of these compounds have an equant form and density of 3.6 to 3.3 . If these materials are screened so that grains are of one size, the resulting material will have a calculated porosity from 27 to 40 percent, depending on the packing pattern as close pack or random. With such porosity, the bulk density ranges from 2.1 to 2.6 , or roughly that of salt. Ideally, poorly sized material could yield a higher bulk density, if that is desired. In this study it was found that the materials could not be packed to this ideal porosity. An advantage of equant material is that with sizing, there is some control over the porosity and therefore the bulk density. This permits modeling the backfill to be most appropriate for the geological condition and the expansion accompanying the hydration reaction. Mgo and $\mathrm{Ca}_{2} \mathrm{SiO}_{4}$ are hard materials, but with a reduction in grain size, the rate of hydration increases and the possibility of damage by abrasion would be decreased.

The kinetics of the hydration reactions of MgO and variants of $\mathrm{Ca}_{2} \mathrm{SiO}_{4}$ were established by timed experiments at room temperature, $60 \mathrm{C}$, and $150 \mathrm{C}$. Several carefully sized fractions of the different materials were used so that the results can be related to surface area. The reaction products were established by $\mathrm{x}$-ray diffraction and the extent of the reaction was determined by TGA and DTA, which showed the water loss with heating.

Another phase of the study involves the measurement of the thermal conductivity of the backfill material. Since the canistered waste is a heat source, the backfill material should have sufficient thermal conductivity to prevent excessive buildup of heat. The thermal conductivity will be a 
function of the properties of the crystals, grain size, and especially packing. However, because the backfill material is a powder and there is significant porosity, it is certain that the backfill material will have poorer thermal conductivity than the surrounding rock. Mgo and the variants of dicalcium silicate have a high density, crush with an equant habit and therefore pack easily, and consequently should have better thermal conductivity than bentonite, fine-grained Mgo, zeolites, and other materials that have been proposed for backfill. Part of this research was to measure the thermal conductivity of Mgo, bentonite, and the variants of dicalcium silicate using different packings and grain sizes. Hydrated samples were also used for the thermal conductivity measurements.

\subsection{HYDRATION STUDIES}

\subsection{Hydration of Mgo}

\subsubsection{Background}

Periclase, Mgo, or magnesia is a high capacity desiccating material that hydrates to $\mathrm{Mg}(\mathrm{OH})_{2}$, a compound called brucite. The hydrate contains about 31 percent water, and it is stable to over $300 \mathrm{C}$. In an earlier study (Simpson, 1980) it was shown that Mgo hydrates under a very low vapor pressure of water. For example, at 25C, MgO will hydrate under 0.027 atmospheres of water vapor pressure. At $60 \mathrm{C}$ with very finely divided reagent grade Mgo, Simpson (1980) found that under 0.1 atmospheres of water vapor pressure the hydration of Mgo proceeded rapidly for 6 days. After 10 days, the hydration reaction ceased although the sample contained much unreacted material. Apparently the reaction product $\mathrm{Mg}(\mathrm{OH})_{2}$ armors a residual core of MgO, and this armoring sharply reduces the rate of hydration. This indicates 
that the grain size of the MgO is extremely Important in regard to the kinetics and the extent of the reaction.

A decrease in the grain size of Mgo results in an increase in the rate and extent of hydration. Reagent grade Mgo is a finely divided powder, and therefore highly reactive with water, but it is also an insulating material. Some Mgo is coarse grained or pelletized. Clearly, the grain size affects the rate and extent of hydration and the thermal conductivity. A high rate of hydration is desired; yet the thermal conductivity must be acceptable.

\subsubsection{Procedure}

Some pelletized, commercially avallable magnesia was found to be coarse grained. This material was crushed in a plate mill and mechanically sized using stalniess steel sieves, with the mesh based on the astM scale. The different size fractions were quickly washed in water, rinsed with ethyl alcohol, and dried.

Samples from each size fraction were exposed to water or water vapor for the desired time and temperature under one atmosphere total pressure. Samples at $150 \mathrm{C}$ were sealed in Teflon reaction vessels with water; consequently, the pressure for the reaction is very nearly the vapor pressure of water at $150 \mathrm{C}$. This vapor pressure is about 4.7 atmospheres.

After the desired period of hydration, the partially hydrated material was dried at $150 \mathrm{C}$ to remove interstitial water, the dried sample weighed, reheated to $630 \mathrm{C}$ to liberate all water of crystalization, and then rewelghed. This establishes sample weight and the water of crystallization from which the percentage of hydration is calculated. 


\subsubsection{Results}

The extent of hydration of MgO as a function of grain size is shown in Figure 1. Also shown is the ideal water content of fully hydrated Mgo, which is $\mathrm{Mg}(\mathrm{OH})_{2}$ and contains 31 percent water.

At $150^{\circ} \mathrm{C}$ under a water vapor pressure of about 4.7 atmospheres, Mgo completely hydrates in approximately 10 hours. The hydration of the finest grained sample, less than 62.5 and greater than $31 \mu \mathrm{m}$, was complete in less than two hours.

At $60 \mathrm{C}$, the finest grained sample completely hydrated in 100 hours, but the reaction for the coarsest material was only 20 percent complete. At 20C, all size fractions required more than 1000 hours for extensive hydration.

In summary, a decrease in temperature of reaction from 150 to 60 requires about a 10-fold increase in time for the same degree of hyaration. Similarly, a decrease from 60 to $20 \mathrm{C}$ requires about a 10 -fold increase in time for the same degree of hydration. The effect of grain size, and therefore surface area, on rate of hydration is most pronounced at $60 \mathrm{c}$.

Surface area was calculated for the sized fractions used for the hydration experiments. For this calculation, the fragments were considered spherical, with the diameter of the sphere taken as the mesh opening of the screen on which the sample was retained during sizing. A plot of the calculated surface area versus water of crystallization under a glven time and temperature is shown in Figure 2. A fully hydrated product contains 31 percent water of crystallization. For example, a sample with uniform particles with a surface area of $2 \times 10^{4} \mathrm{~mm}^{2} / \mathrm{gram}$ would have about 20 percent water of crystallization after 200 hours at $60 \mathrm{C}$. Since a fully hydrated sample contains 31 percent water of crystallization, the sample containing 20 


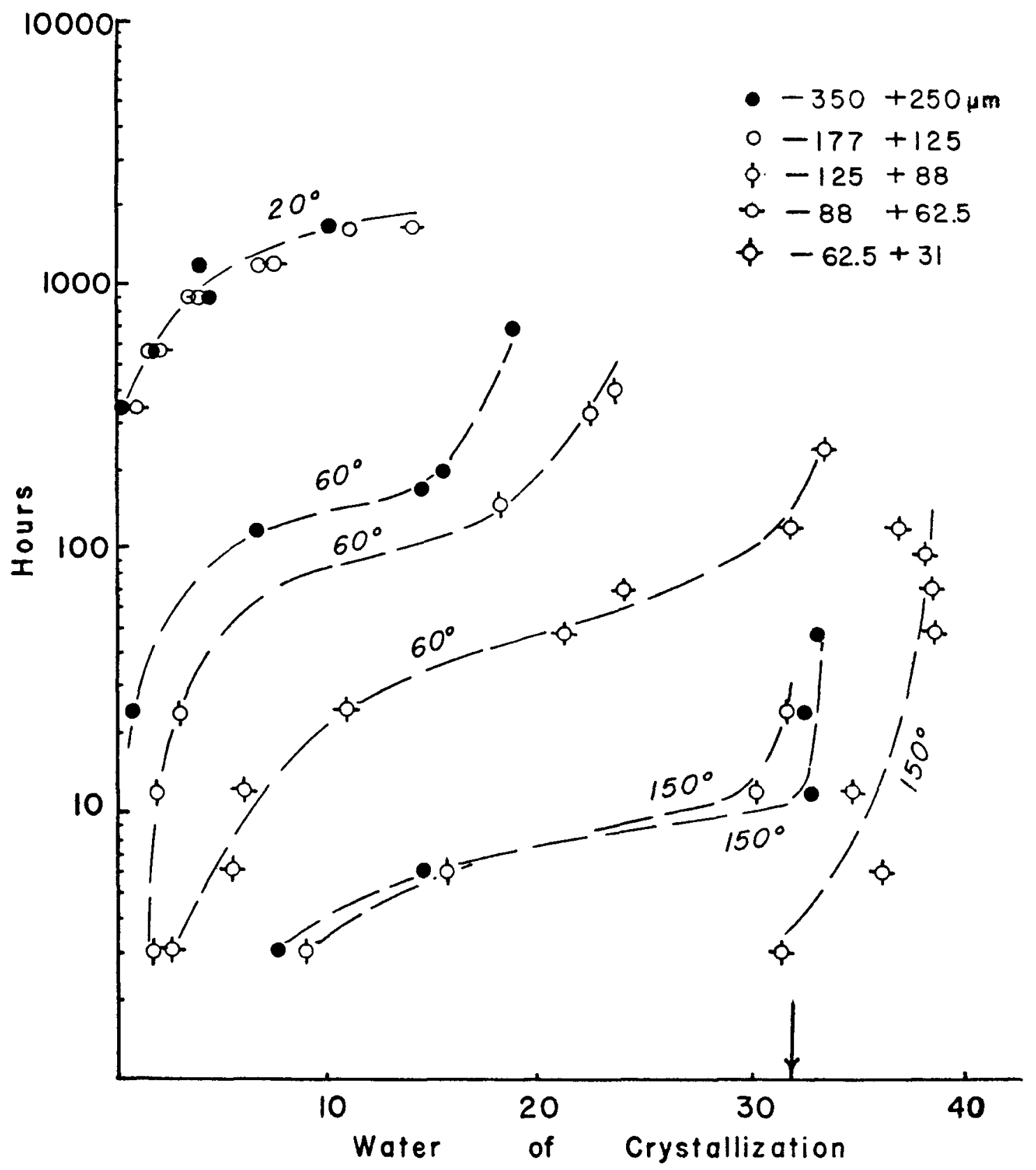

Figure 1. Hydration of MgO as a function of grain size. Note: Completely hydrated $\mathrm{MgO}$ contains $31 \%$ water, as indicated by the arrow on the abscissa. 


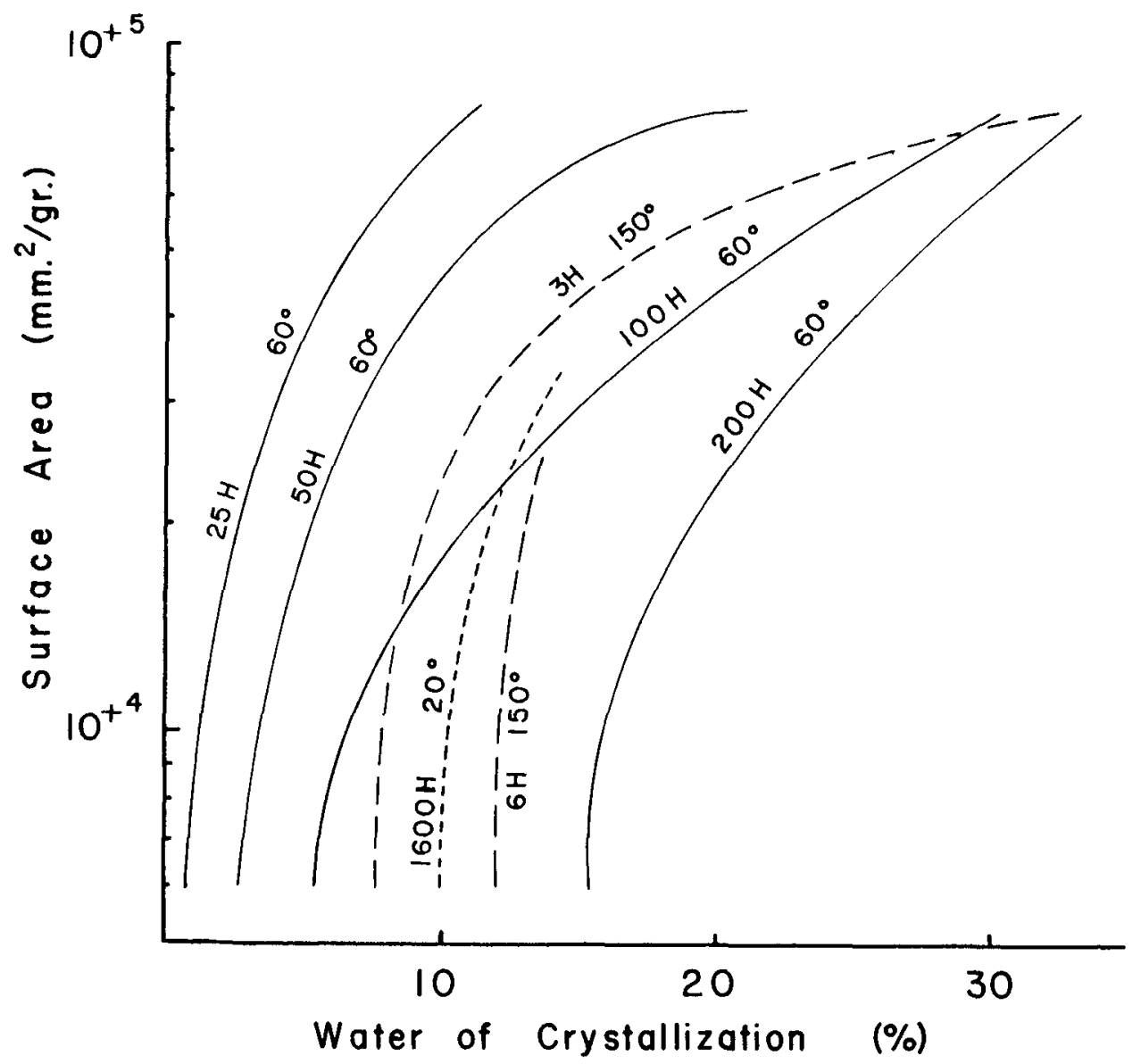

Figure 2. Hydration of $\mathrm{MgO}$ as a function of surface area for different times $(\mathrm{H}=$ hours $)$ and temperatures $\left({ }^{\circ} \mathrm{C}\right)$. 
percent water of crystallization indicates that 65 percent of the hydration reaction is completed. With the same temperature and time a sample with a surface area of $6 \times 10^{3} \mathrm{~mm}^{2} / g r a m$ would be 50 percent hydrated, and a sample with a surface area of $6 \times 10^{4} \mathrm{~mm}^{2} / \mathrm{gram}$ would be completely hydrated under the same conditions. Given a surface area of $2 \times 10^{4} \mathrm{~mm}^{2} / \mathrm{gram}$, Figure 2 shows that approximately the same degree of hydration is achieved in 1600 hours at 20C, 100 hours at 60C, or 6 hours at 150C. This degree of hydration is about 40 percent of a fully hydrated material. With interpolation, this diagram can be used to estimate the rate of hydration of Mgo as a function of surface area, time, and temperature.

\subsection{Hydration of Variants of $\mathrm{Ca}_{2} \mathrm{SlO}_{4}$}

\subsubsection{Background}

Dicalcium silicate $\left(\mathrm{Ca}_{2} \mathrm{SiO}_{4}\right)$ is a major phase in portland cement. This compound has many polymorphs, but it is the high-temperature polymorphs which hydrate to tobermorite, that is the cement bonding material. The high temperature compounds are unstable thermodynamically, and they invert over a long period to a low temperature polymorph that has poor cemerting properties. If the high temperature polymorphs can be preserved, dicalcium silicate has potential as a backfill desiccant, because with hydration the structural integrity of the system is reestablished. Earlier research demonstrated that several of the high-temperature polymorphs of $\mathrm{Ca}_{2} \mathrm{SlO}_{4}$ could be stablized by doping the compound with $\mathrm{CaNaPO}_{4}$. These stabilized compounds are the 3 and $\alpha$ forms of $\mathrm{Ca}_{2} \mathrm{~S}_{2} \mathrm{O}_{4}$ doped with 10 mole percent

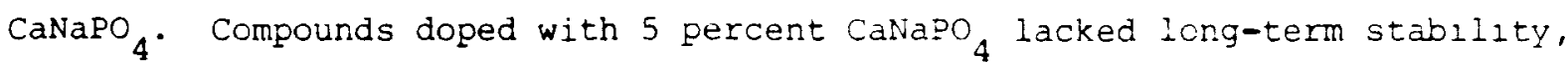
and they invert to a form called $y$. 
The stabilized, high-temperature forms of $\mathrm{Ca}_{2} \mathrm{SiO}_{4}$ can be preserved; however, the effect of this stabilization on the rate of hydration was unknown. For this reason, hydration experiments were conducted on stabilızed high-temperature forms of $\mathrm{Ca}_{2} \mathrm{SiO}_{4}$ and for comparison on material which had partly inverted to the low temperature $\gamma$ forms.

\subsubsection{Procedure}

A high-temperature form of dicalcium silicate was synthesized from a mixture of $\mathrm{CaCO}_{3}, \mathrm{SiO}_{2}$, and $\mathrm{NaH}_{2} \mathrm{PO}_{4}$ heated to $1380 \mathrm{C}$ for 48 hours. The product had a composition of $\left.\left.\mathrm{Ca}_{2} \mathrm{SiO}_{4}\right)_{90} \mathrm{CaNaPO}_{4}\right)_{10}$ and it consisted of the high temperature phases. In a similar manner, a product with the composition $\left.\left.\mathrm{Ca}_{2} \mathrm{SiO}_{4}\right)_{95} \mathrm{CaNaPO}_{4}\right)_{5}$ was formed, but this product inverted on cooling to give the low-temperature, $y$, form. These materlals were crushed and sized. Sized fractions were used in the hydration experiments, but microscopic examination showed that all fractions, except the finest, contained aggregates instead of single crystal fragments. As a result, the surface area of the different size fractions cannot be accurately calculated.

The microscopic examination of the size fractions of the low temperature, $\gamma$, form of the doped dicalcium sillcate showed that the synthesized material was heterogeneous. The inversion to $Y$ involves a large volume change that causes the synthesized product to crumble. However, only about 28 percent of the material inverted to the low temperature, $\gamma$, form, and the other 72 percent of the materlal remalned the typlcal high temperature forms. Attempts to separate a pure $y$ form of $\mathrm{Ca}_{2} \mathrm{~S}_{1} \mathrm{O}_{4}$ using heavy liquids and different sieve sizes were unsuccessful. Consequently, hydration experiments involving the $Y$ form are on heterogeneous material of which 28 
percent is $Y$, and the balance is the high-temperature form similar to the high-temperature products with the composition $\left.\mathrm{Ca}_{2} \mathrm{~S}_{1 O_{4}}{ }^{\prime} 90^{\prime} \mathrm{CaNaPO}_{4}\right)_{10}$ Both the $\gamma$ bearing material and the synthesized material lacking the form were reacted in water at 20,60 , and $150 \mathrm{C}$ in a manner similar to the Mgo. After reaction, the products were $\mathrm{X}$-rayed and the water of crystallization expelled by heating. Differential thermal analysis was completed on some products.

\subsubsection{Results}

Stabilized high-temperature dicalcium silicate was maintained under water for periods to 1300 hours at $20 \mathrm{C}$. After drying at $150 \mathrm{C}$ to eliminate surface water, no additional water was expelled by heatıng to $630 \mathrm{C}$, a temperature above the stability temperature of any hydrous product for this system. Thus no hydrous compound was formed in detectable amounts that had thermal stability above $150 \mathrm{C}$, the temperature at which the products were dried after the attempted hydration.

At 600 the stabilized dicalcium silicate reacted partially to yleld hydrous compounds, as shown by a 1 to 2 percent water loss with heating from 150 to $630 \mathrm{C}$ (Figure 3). An $\mathrm{X}$-ray shows that the compound is hillebrandite $\left[\mathrm{Ca}_{2} \mathrm{~S}_{10}(\mathrm{OH})_{2}\right]$, but it has poor crystallinity. Hillebrandite contains about 10 percent water, indicating that after 550 hours at $60 \mathrm{C}$ only 10 to 20 percent of the stabilized dicalcium silicate had hydrated. Particle size has a significant effect on the reaction rate even though the coarser sizes were aggregates of crystals. Material in the size range of 62.5 to $88 \mathrm{\mu m}$ is about twice as reactive as material in the size range of 125 to $177 \mu \mathrm{m}$ or 250 to $350 \mathrm{\mu m}$. 


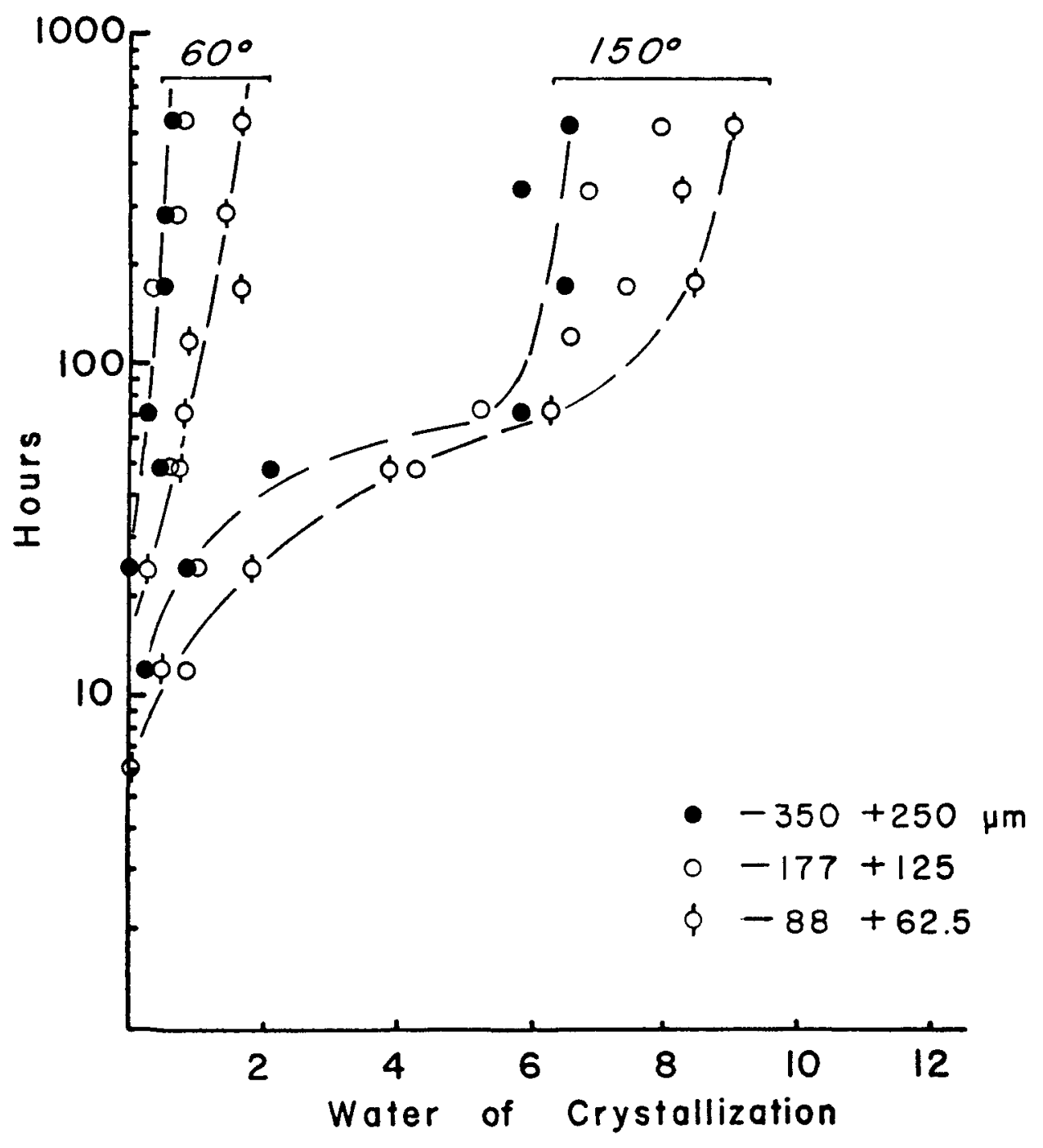

Figure 3. Hydration of doped $\mathrm{Ca}_{2} \mathrm{SiO}_{4}$ as a function of grain size. Note: Hillebrandite, the hydrous product, ideally contains about 10 : water of crystallization. 
At $150 \mathrm{C}$, under a total pressure of 4.7 atmospheres, dicalcium silicate was extensively hydrated in 70 hours to hillebrandite. After 550 hours, the material contained 6 to 9 percent water depending on the grain size of the starting material. In comparison, hlllebrandite, the product ldeally contains about 10 percent water (Figure 3).

The $\gamma$ bearing fraction of dicalcium silicate was reacted at 20 and $150 \mathrm{C}$. The $Y$ phase is the less reactive low temperature phase. The sample contained 28 percent $\gamma$ and the balance appeared to be the usual high temperature phases.

At $20 \mathrm{C}$ the $\gamma$ bearing material falled to hydrate in 1300 hours, and at $150 \mathrm{C}$ for 1300 hours only 2 percent water of crystallization was contalned in the product. Thus, the $\gamma$ bearing material is only 20 to 30 percert as reactive as the stabilized high temperature dicalcium silicate. Consequentiy, to maintain the most reactive dicalcium silicate, the inversion to the $\gamma$ form must be prevented. This can be accomplished by the substitution of 10 mole percent $\mathrm{CaNaPO}_{4}$ in the high tempezature dicalcium silicate structure.

In comparison, the extent and rate of hydration and the stability of tre hydrates of dicalcium silicate are inferior to that of Mgo. The hydrates of dicalcium silicate have a cementous nature, whereas the hydrates of Mgo form a noncoherent mass. 


\subsection{Hydration of Bentonite}

\subsubsection{Background}

Bentonite is a finely divided clay that has attracted considerable attention as a backfill material. Bentonite is considered an expandable clay because it expands in the course of reacting with water. It has a high ion exchange capacity. Bentonite is the clay name for the mineral group called montmorillonite.

Montmorilionite, from the western United States, commonly contains an alkali between layers of the structure, and such montmorillonite expands when wet and forms a paste-like mass. Montmorillonite from the eastern united States, or when associated with calcium or magnesium carbonate rocks, commonly contains an alkaline earth between the layers; this montmoriilonite fails to show the extensive expansion, suggesting that bentonite used as backfill could undergo ion exchange and lose some of its desired properties in regard to radioisotope sorption and hydration.

Bentonite has a low thermal stability, and with heating will release sorbed and water of crystallization. Thus, bentonite may serve as a low temperature sorbent for water and radioisotopes and expand. However, with heating to less than $150 \mathrm{C}$ in an open system, hydrated-expanded bentonite will release the water and may release the radioisotopes. In a closed system, the hydrated bentonite will retain water to a higher temperature. Consequently, bentonite, which is a low temperature sink, becomes a moderate temperature source. Because of this nature the hydration and properties of bertonite were determined for comparison to the reaction of the mineral in brine. 


\subsubsection{Procedure}

Commerclally available bentonite from Osage, Wyoming was used for all experiments. The material is a finely divided powder. The stock material was $x$-rayed to determine the interlayer spacing before and after heat treatment. Thermogravimetric analysis (TCA) and differential thermal analysis (DTA) were completed to determine the temperature at which there is weight loss or energy changes.

Stock bentonite was reacted with water at 20,60 , and $150 \mathrm{C}$ and the product determined wath $\mathrm{X}$-ray diffraction.

\subsubsection{Results}

Stock bentonite was slowly heated in a thermogravimetric apparatus. Weight loss began at $30 \mathrm{C}$ and was continuous to $105 \mathrm{C}$ with the total welght loss being nearly 10 percent. There was no further welght loss with heating to 330C. With DTA the first distinct endotherm starts at 105C; however, background drift beginning at $20 \mathrm{C}$ may represent the loss of sorbed water. A broad small endotherm starts at $680 \mathrm{C}$. The $\mathrm{X}$-ray diffraction results for this untreated stock bentonite are given in Table 1. A distınctive feature of this $\mathrm{X}$-ray pattern is a strong basal reflection at $13.0 \AA$. This basal reflection 15 subject to change with hydration or dehydration. After drying at $150 \mathrm{C}$, the basal reflection is reduced to $10 \AA$.

Stock bentonite was hydrated in water at $20 \mathrm{C}$ for 140 days and then $x$-rayed by using the molst sample slurried with alcohol on a slide. There are two basal reflections. Cne 1 s at 20.8 and the other 15 at $15.3 \mathrm{~A}$.

After 140 days at $60 \mathrm{C}$ in water, the reacted bentonite showed a Dasal reflection at $20.2 \AA$ and another at $15.6 \AA$. This indicates that the hydration involved substantial expansion of the bentonite. 
TABLE 1

$X$-Ray Diffraction Data for Bentonite

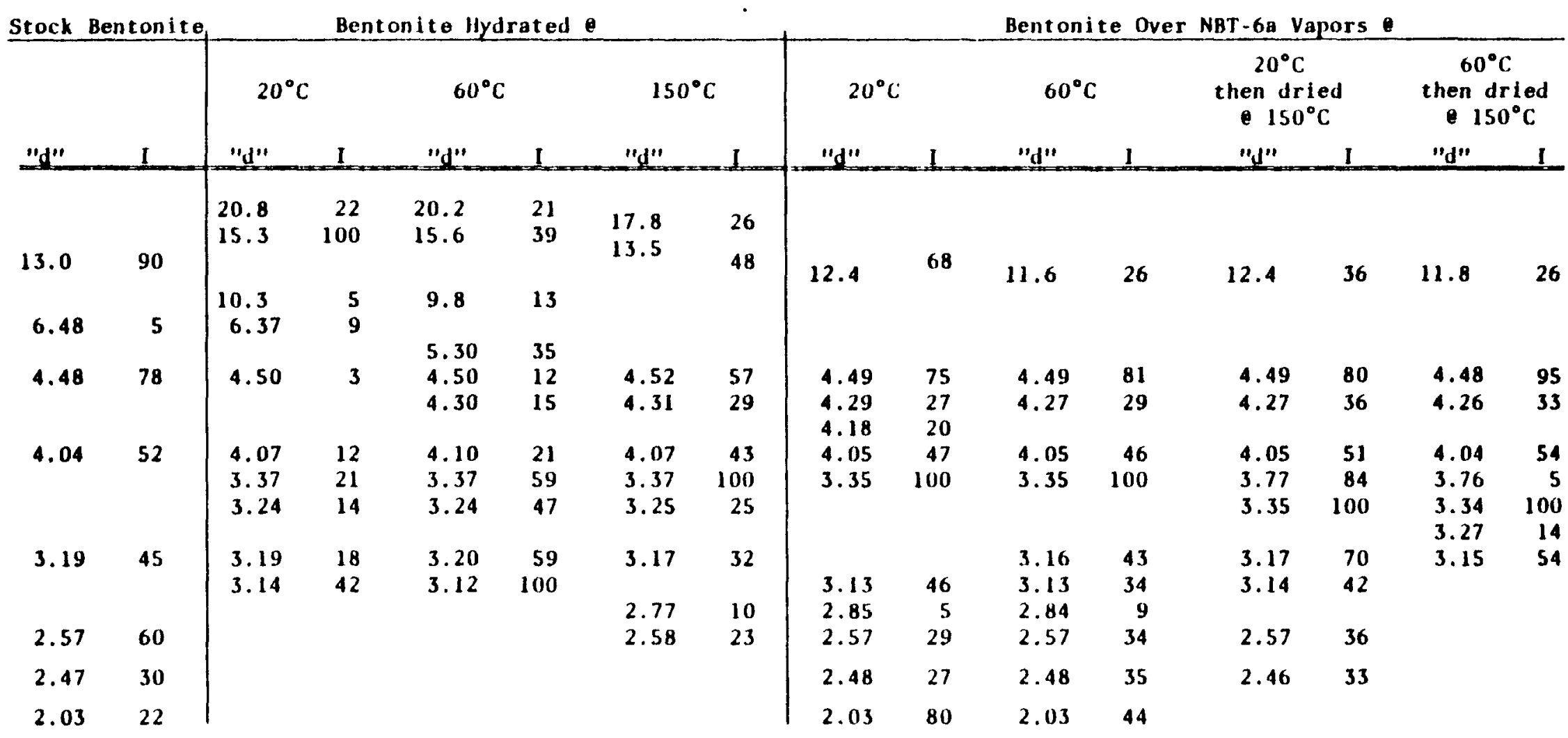


Bentonite under water at $150 \mathrm{C}$, at a pressure of 4.7 atmospheres for 140 days, gave a new basal reflection at $17.7 \AA$ and a basal reflection at $13.5 \AA$. The $13.5^{\circ}$ may correspond to the $13.0^{\circ}$ of the untreated material. The complete $\mathrm{X}$-ray diffraction data is shown in Table 1.

\subsubsection{Hydration with Low Vapor Pressure}

With increasing salt concentration, the water vapor pressure of a solution is decreased. For example a 6 molar NaCl solution lowers the vapor pressure of water by 23 percent. A brine as NBT-6a contains 10 percent $\mathrm{MgCl}_{2}, 10$ percent $\mathrm{CaCl}_{2}, 5$ percent $\mathrm{NaCl}$, and 5 percent $\mathrm{KCl}$ and, as a result, the lowering of the vapor pressure is more pronounced than with NaCl. Using the data presented by Simpson (1980), the water vapor pressure of an NBT-5a type brine at $60 \mathrm{C}$ is about 0.1 atmospheres, and at $20 \mathrm{C}$ it is .011 atmospheres. In comparison, pure water has nearly twice the vapor pressure at these temperatures, namely 0.196 and 0.023 atmospheres, respectively.

Since bentonite reacts with water and expands, the possibility of desiccation under reduced vapor pressure must be considered. For this reason, samples of stock bentonite were exposed to the water vapor from the NBT-6a brine at $20 \mathrm{C}$ and $60 \mathrm{C}$ for 112 days. As shown in Table 1 , stock bentonite has a basal spacing at $13.0 \AA$, but long exposure to the lowered water vapor pressure at $20 \mathrm{C}$ reduced the basal spacing to $12.4 \AA$. Exposure to the low vapor pressure at $60 \mathrm{C}$ reduced the basal spacing to $11.6 \AA$. Brines are a desiccant. These experiments show that NBT-6a brine is a sufficiently strong desiccant to provide a vapor phase which will remove water from the stock bentonite, which appears as a dry powder, and partially collapse the structure as shown by the reduced basal spacing. This desiccation is caused by a drying vapor and is not the result of reaction of ions in the brine with 
the mineral. Such contraction of the bentonite by the drying vapor results in increased porosity. As will be presented in a later section, heat flow decreases as the porosity increases.

\subsection{REACTION OF BENTONITE WITH BRINE}

\subsection{Background}

Bentonite readily undergoes Ion exchange which causing a change in the basal spacing. For example, there are sodium bearing bentonites and calcium bearing bentonites, and these different compounds have desiccating properties and expansion in water. Ion exchange, as a surface-related process, occurs rapidy compared to diffusion of lons within a crystal. However, both the surface lons of a crystal and those within a crystal can be exchanged, and the exchange process is accelerated by increased temperature.

Bentonite, or the mineral montmorilionite, undergoes ion exchange with magnesium, calcium, and the alkali lons depending on the activity of these ions in a solution. It has been suggested that a magnesium exchanged montmorilionite with heat treatment may undergo a magnesium ion "place exchange" in that the magnesium ion migrates from the interlayer site to an octahedral site (Theng, 1974). Such a "place exchange" of sorbed lons will change the properties of the montmorilionite and if extensive, may lead to a new compound.

Montmorilicnite lacks a unique composition; however, a typical formula given Dy Fleischer (1974) is shown in Table 2. For comparison, the formula for vermiculite is also given. The two groups of minerals are similar; the major difference is that the montmorilonites contain two lons in three octahedral sites, whereas the vermiculites contain three iors in the three 
sites. Thus, a place exchange in an interlayer magnesium of montmorilionite yields an additional ion for an octahedral site, thereby making the compound a vermiculite. The distınction between montmorillonite and vermiculite can be difficult because one can grade into the other. The physical and chemical nature of the two groups is different, but the intermediate compositions may have intermediate properties. The distinction and identification of clays is further complicated by some compounds having mixed layers; ramely, layers of one type of clay are interspersed with layers of a second type of clay.

Table 2

Representative Formulas of Montmorilionite and Vermiculite

\begin{tabular}{|c|c|}
\hline Name & Formula \\
\hline Montmorillonite & 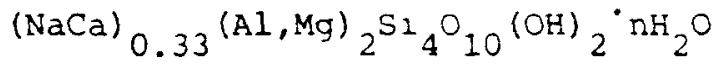 \\
\hline Vermiculite & 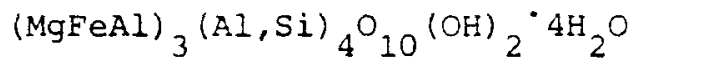 \\
\hline
\end{tabular}

Clays are commonly identified on the basis of a characteristic basal spacıng as determined by $x$-ray diffraction. Some clays, of which montmorillonite is an excellent example, sorb organic molecules such as ethylene glycol. These organic molecules may change the basal spacirg. For example, montmorilionite is expanded by the sorption of ethylene glycol, whereas vermiculite undergoes a lesser expansion. The behavior of clays in the presence of organic molecules alds in their identification. Differential thermal analysis (DTA), which records the temperature of endothermıc and exothermic reactions, is also useful for identification. All of these 
methods were used, but the basic problem remains the gradational nature between the montmorillonite and vermiculite groups.

\subsection{Procedure}

Stock bentonite was mixed with a synthetic brine, NBT-6a. This brine contains 30 percent salts of $\mathrm{CaCl}_{2}, \mathrm{MgCl}_{2}, \mathrm{NaCl}$, and $\mathrm{KCl}$. On a mole basis, the brine is slightly enriched in $\mathrm{MgCl}_{2}$ and depleted in $\mathrm{KCl}$ relative to the $\mathrm{CaCl}_{2}$ and $\mathrm{NaCl}_{2}$. The bentonite, $10 \mathrm{grams}$, and $10 \mathrm{ml}$. of brine, were sealed in plastic bottles and mantained at 20 and $60 \mathrm{C}$ for 100 days, then resealed and maintained for a total of 250 days. Similar samples were sealed in Tefion containers in a pressure vessel at 150 and $200 \mathrm{C}$ for 100 days and 50 days, respectively.

After reaction with the brine, part of the sample was mixed with alcohol and an X-ray diffraction slide prepared. The prepared mount alr dried before x-raying. The remaining reacted material was air dried or dried over silica gel before DTA and other determinations were made.

Some reacted material was repeatedly washed in water to determine the reversibility of the reaction. This washed material was dried over silica gel.

The reacted material, after the inıtial $x$-rays were completed, was exposed to ethylene glycol vapors. The same $x$-ray mounts were rex-rayed to determine the effect of glycolation.

Thermogravimetric analysis and DTA runs were made with material air dried, or dried over silica gel, using a heating rate of $4-5 \mathrm{c}$ / minute. 


\subsection{Results}

Stock bentonite reacted with NBT-6a type brine showed an expansion from $13.0 \AA$, for the basal spacing of the untreated bentonite, to $15.2 \AA$ for reacted material at $20 \mathrm{C}$ for 100 days. Reacted material at $60 \mathrm{C}$ and $150 \mathrm{C}$ over 100 days gave basal spacings of 14.7 and $13.8 \AA$, respectively (Table 3 ). Thus, the reaction of bentonite with brine causes an increase in the basal spacing of the clay. However, this increase is diminished at increased temperatures of reaction.

After 250 days, bentonite reacted with brine at 20 and $60 \mathrm{C}$ gave basal spacings of 14.0 and $12.8 \AA$, respectively (Table 3 ).

A single experiment was conducted at $200 \mathrm{C}$ for 50 days. The product had a basal spacing of $13.0 \AA$.

Bentonite reacted with brine at $150 \mathrm{C}$ was heated in air to $150 \mathrm{C}$. There was no change in the basal spacing after reaction compared to the reacted material heated in air. For comparison, untreated bentonite is dehydrated and the basal spacing reduced to $10 \AA$ with heating to $150 \mathrm{C}$.

Thus, a reaction with the brine produces a compound with increased thermal stability.

To summarize, the brine reacts with bentonite to yield a clay with an increased basal spacing. The increase is diminished by increasing temperature from 20 to 200C. It is further diminished by increasing time from 100 to 250 days at 20 to $60 \mathrm{C}$ (Figure 4). Both the time and temperature effects indicate that the reaction is sluggish, and is therefore more than a surface process. Furthermore, the kinetics, temperature, and basal spacing effects suggest a reaction as the "place exchange" reaction where the 
TABLE 3

$X$-Ray Diffraction Data of Bentonite and Reaction Products

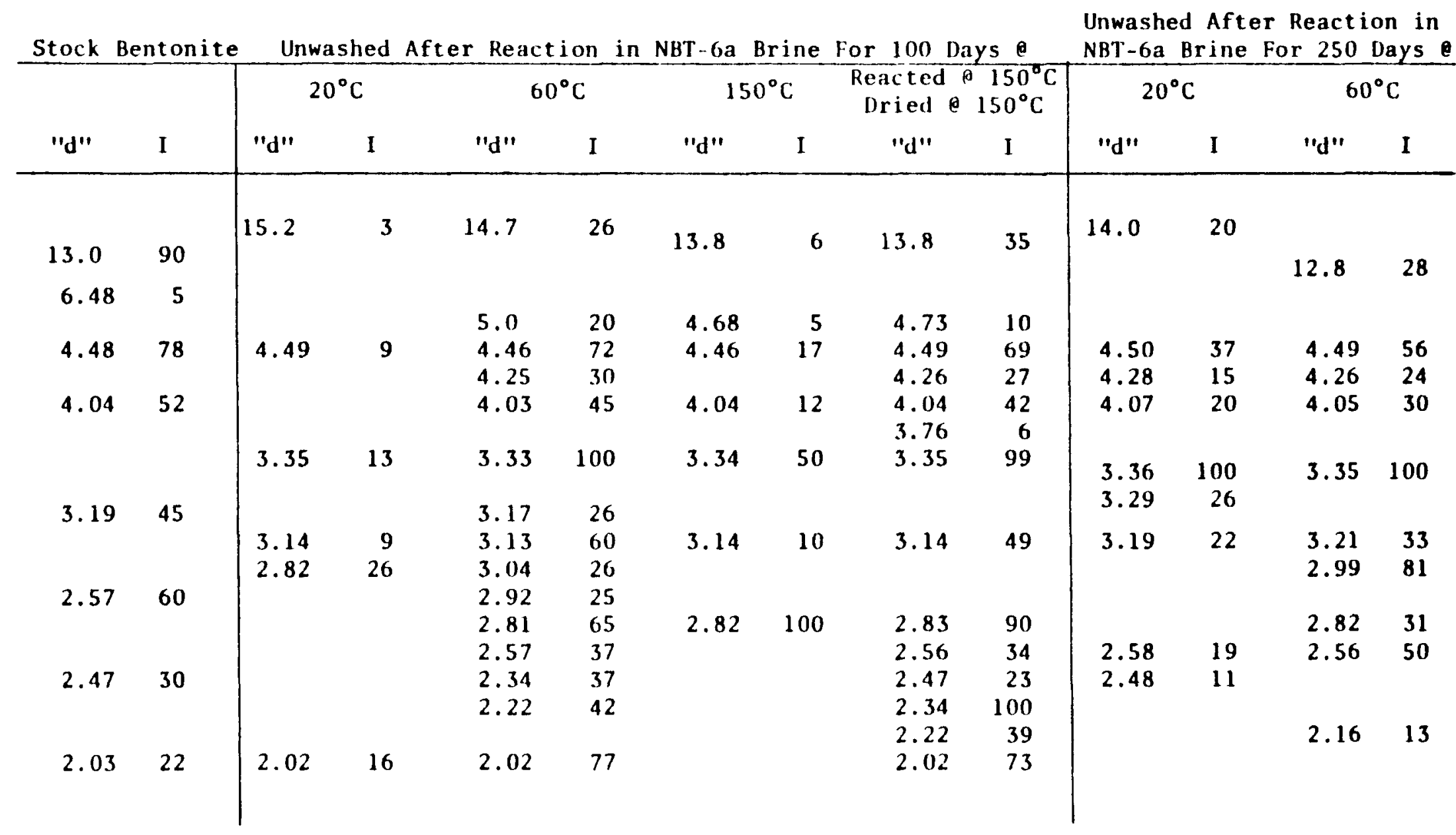




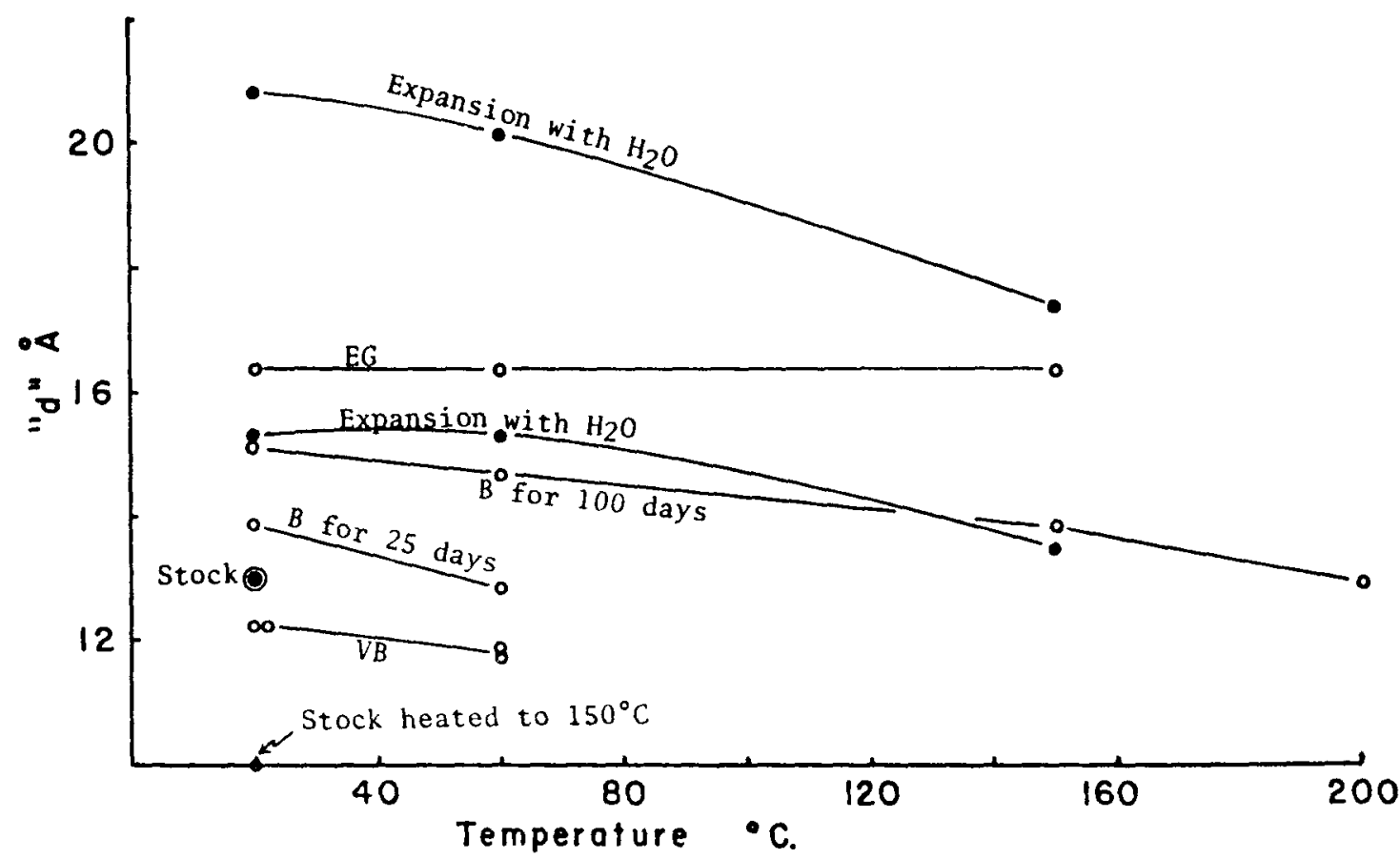

Figure 4. Basal spacing of bentonite and its reaction products at different temperatures.

Note: $\mathrm{B}=\mathrm{NBT}-6 \mathrm{a}$ brine, $\mathrm{VB}=$ water vapor from NBT-6a brine, $\mathrm{EG}=$ treatment with ethylene glveol of profuct from NBT-fa brine reaction after 100 days. 
interlayer alkaline ion migrates to a vacant octahedral site. This new compound has increased thermal stability.

After exposure to ethylene glycol, both the reacted and the unreacted clays have a basal spacing of $16.4 \AA$.

DTA of clays principally show the temperature at which water is expelled. Stock bentonite shows the start of an endothermic reaction at about $115 \mathrm{C}$ and the maximum thermal effect at $160 \mathrm{C}$. In contrast, bentonite reacted with brine at $20 \mathrm{C}$ shows two endotherms. The first begins at 180 with a maximum at $190 \mathrm{C}$, and the second begins at 250 with a maximum at $270 \mathrm{C}$. The condition of the reaction, nature of the sample, total weight loss, and graphic DTA data is given in Table 4. All reacted-unwashed bentorite has two distinct endotherms at higher temperatures than the single endctherm of the stock bentonite. The two endotherms are shifted to lcwer temperatures as the brine-bentonite reaction temperature is increased. Or, in view of the $x$-ray data, the two endothermic peaks are shifted to lower temperatures concomitantly with the decreased basal spacing of the reacted bentonite. Bentonite reacted with brine at $150 \mathrm{C}$ and then repeatediy washed in water shows a single endotherm peaking at 190C. In contrast, untreated bentonite has an endotherm peak at $160 \mathrm{C}$. This indicates that the reacted bentonite cannot be washed without modification of the product.

Since the reacted bentonites were unwashed, the possibility that one of the endotherms is from salts from the brine was investigated. Salts from the brine gave a large sharp endotherm at $180 \mathrm{C}$ and several small endotherms at lower temperatures. Mixtures of 10 and 20 percent salts with the stock bentonite still showed the $180 \mathrm{C}$ endotherm. The mixture of 20 percent salt and stock bentonite also showed a $260 \mathrm{C}$ endotherm, whlch is lacking in the 
pure salt DTA pattern. The 260 endotherm of the 20 percent salt-bentonite mixture is probably the result of a salt-bentonite reaction during the DTA heating cycle. The distinctiveness and the peak positions of the salt DTA pattern preclude the possibility that either of the two endotherms of the reacted bentonite are the result of salt contamination. Thus, a characteristic feature of the reacted bentonite is the double endotherms between 160 and $280 \mathrm{C}$. The precise position of the two endotherms depends on the nature of the reaction product, which is a function of the time and temperature of the reaction (Tables 3 and 4 ).

The scanning electron microscope was used to determine the morphology of the stock bentonite and the reacted material. As shown in Figure 5, there is no distinct morphological difference between the stock bentonite and the reacted material.

\section{4 summary}

Bentonite used in the experiments reacted with the NBT-6a composition brine. The initial product of the reaction shows an increased basal spacing compared to unreacted bentonite, but with extended time, or increased temperature of reaction, the basal spacing approached $13 \AA$, a value which fortuitously is the value of the unreacted material. The reaction product contains more water, yet it has increased themal stability. Bcth unreacted and reacted bentonite expanded to yleld a basal spacing of $16.4 \AA^{\circ}$ when exposed to ethylene glycol. A characteristic feature of the reacted bentonite is two endothermic reactions with heating from 160 to $280 \mathrm{C}$; whereas, unreacted bentonite has a single endotherm at a lower temperature. Firaliy, a distinct 
Table 4. DTA and Weight Loss Data for Bentonite and its Reaction Products

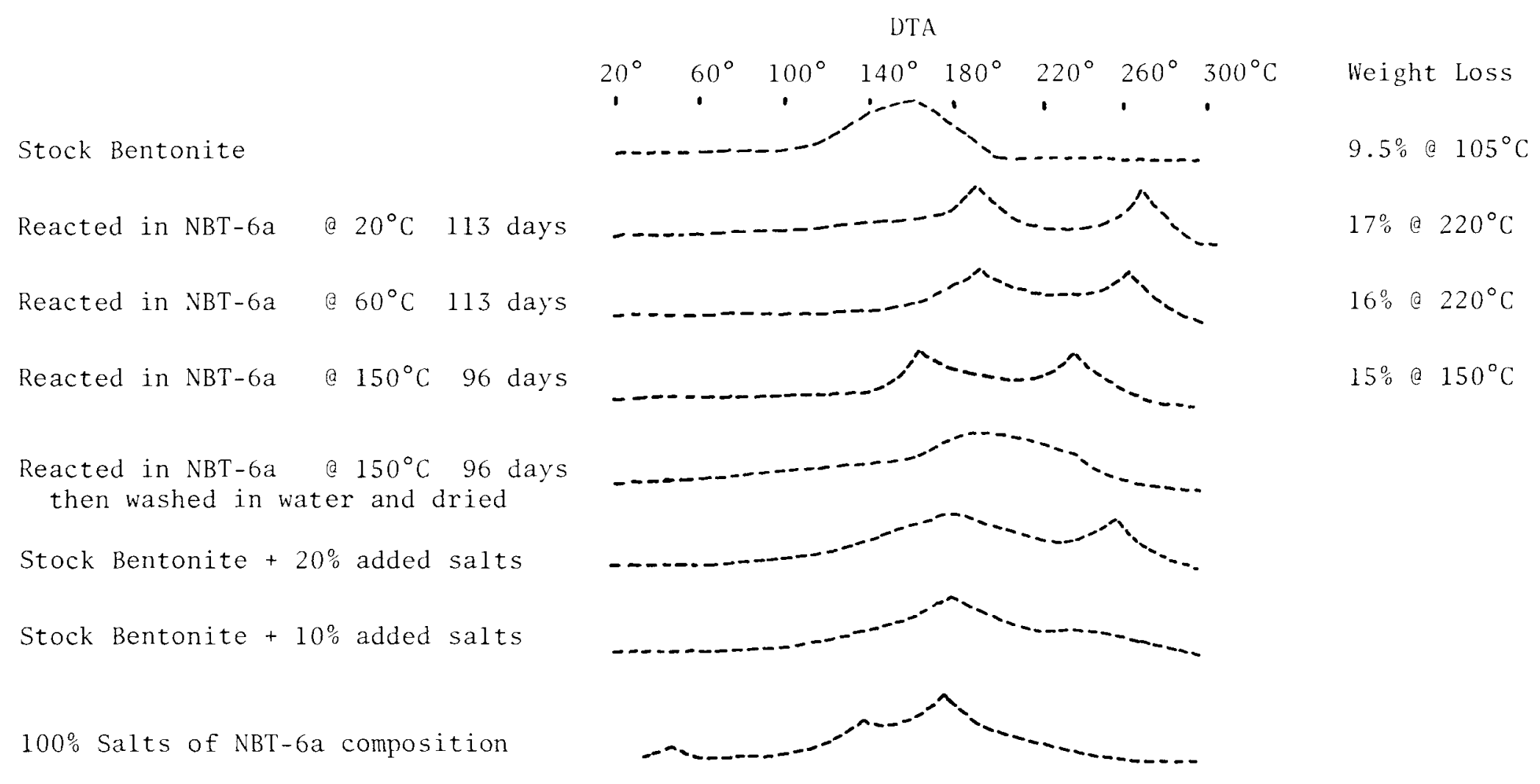




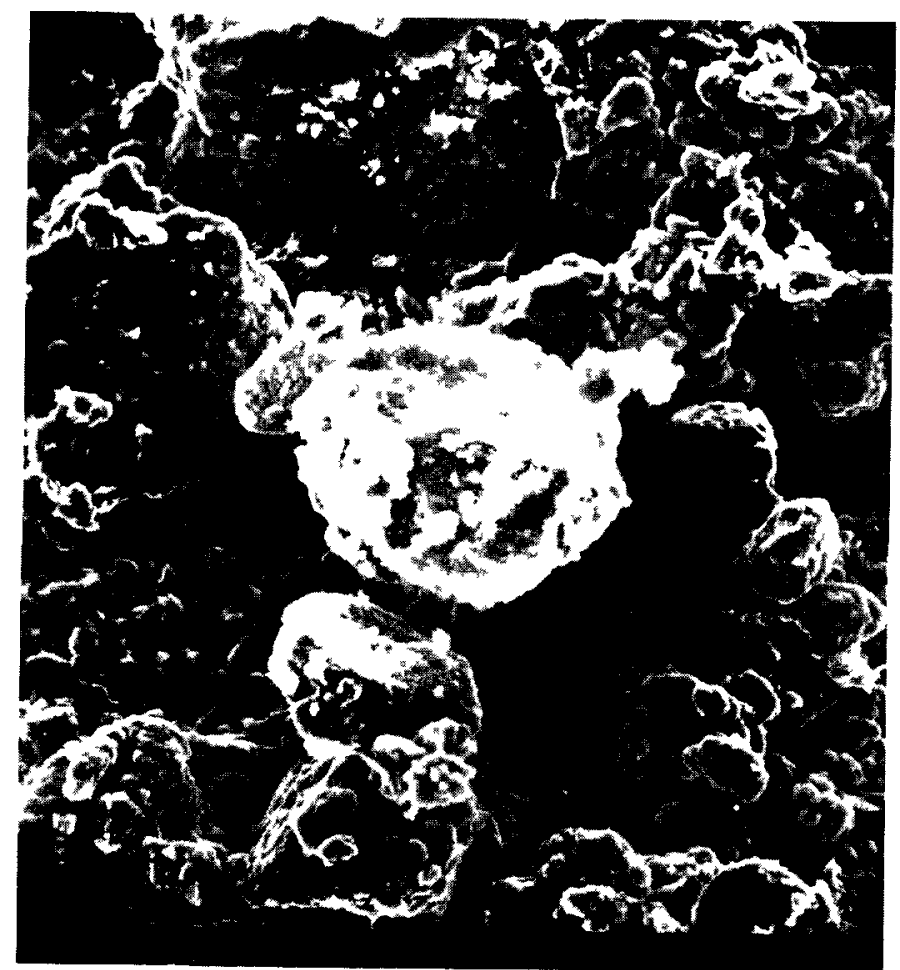

Stock

Bentonite

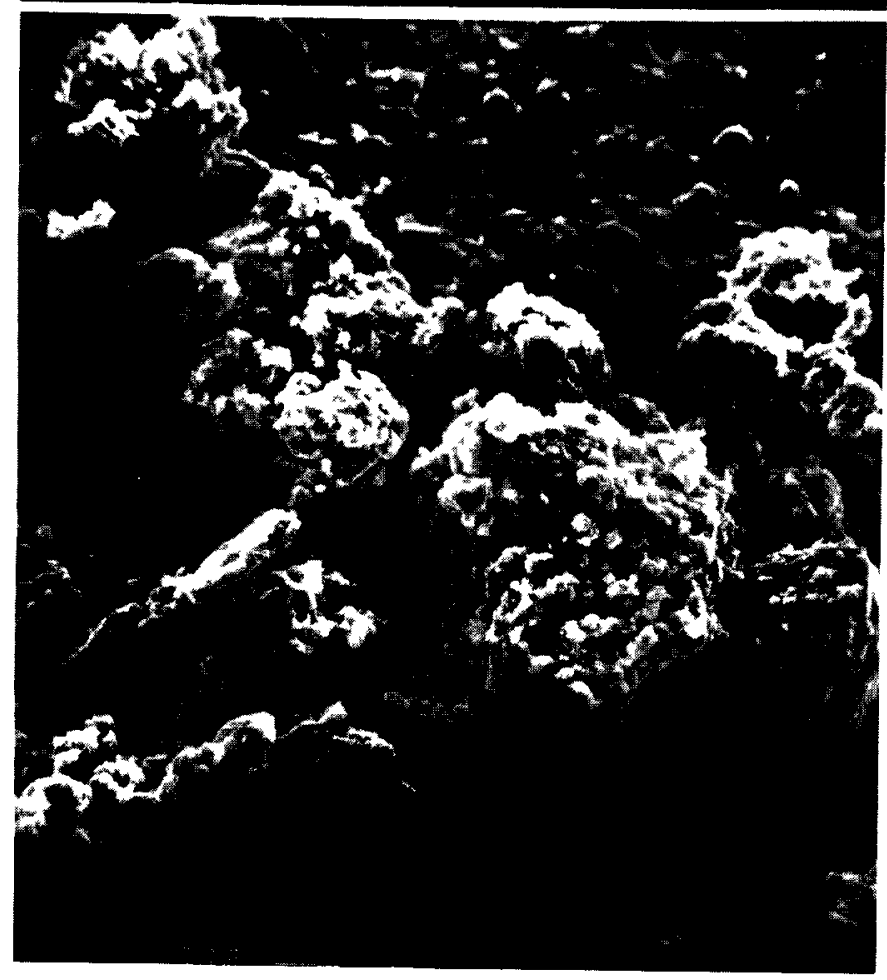

After

Reaction

Figure 5. SEM of stock bentonite and bentonite reacted in NBT-6a brine at $150^{\circ} \mathrm{C}$ for 96 days. Scale bar is $10 \mu \mathrm{m}$. 
morphological difference between the reacted and unreacted bentonite is lackıng.

These findings indicate that the bentonite reacted with the brine. The initial reaction was probably an ion exchange and the long term reaction is a "place exchange" where the sorbed magnesium ion migrates to and occupies an octahedral site of the clay. With such site occupation by magnesium, the bentonite becomes a vermiculite. The data clearly indicates that the change is gradational and the ion exchange process involves the entire crystal framework and not just the surface. The DTA patterns of the reaction products are identical to published patterns for vermiculite. Typical vermiculite is not considered to expand to $16.4 \AA$ when exposed to ethylene glycol; however, the reaction products, concluded to be verm_culite, did expand. This may indicate that the reaction was incomplete or the product is atypical because of other ion exchange.

\subsection{THERMAL CONDUCTIVITY MEASUREMENTS}

\subsection{Background}

Many of the materials which are reactive, desiccants, and sorbents have these properties because they tend to be finely divided and therefore have a large surface area. Finely divided material has a high porosity which imports thermal insulating properties. Thus, in selecting a raterial, the desiccant and sorbent properties must be considered with regard to the thermal conductivity. This selection should be further evaluated in view of thermal conductivity data obtained on backfill materials after they have reacted with water. Such reaction with water will change the porcsity of the backfill and the thermal properties of the reaction products. Because of a 
paucity of data, thermal conductivity was measured for several backfill candidate materials before and after hydration.

There are many types of apparatus for measuring thermal conductivity. One method involves a cylinder, packed with the sample, with a heating wire coaxial with the cylinder. The thermal gradient from the wire to the perimeter and the energy imput is measured. From this the thermal conductivity is calculated. This method is known as the hot wire technique. A modiflcation of this method is to heat the cylindrical sample contalner and sample until they are at a uniform temperature. Then the sample container is cooled and the thermal gradient measured with a thermocouple at tne center of the sample and a second thermocouple at the container wall. With this arrangement, the sample is the heat source and the container the sink. Since energy imput is unmeasured, the measurements lead to thermal diffusivity $(\alpha)$ instead of thermal conductivity $(\lambda)$. The two results are related by considering the density and specific heat of the sample. Thermal diffusivity (a) $=\beta r^{2} / 4 \Delta \mathrm{T}$, which has dimensions of $\mathrm{cm}^{2} / \mathrm{sec}$.

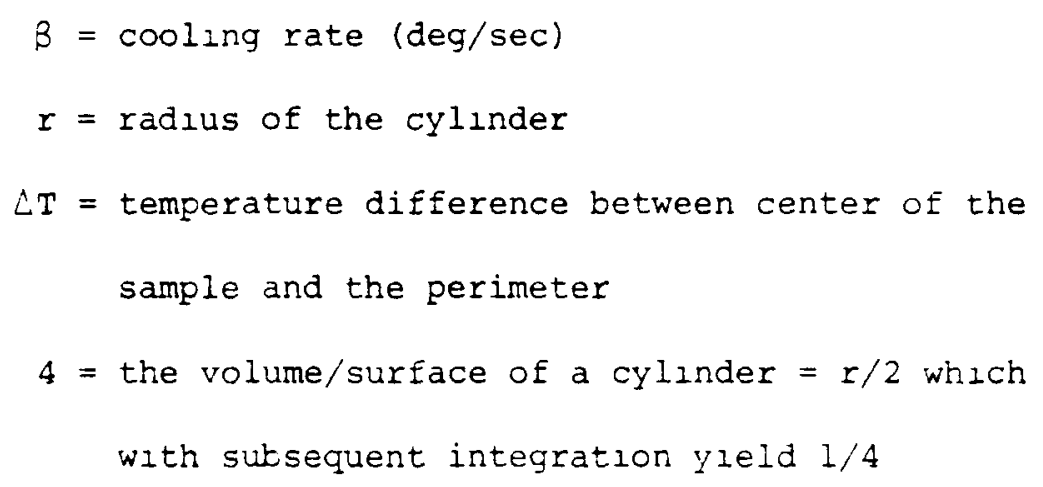


Thermal conductivity $=c$ where

$$
\begin{aligned}
& \alpha=\text { thermal diffusivity }\left(\mathrm{cm}^{2} / \mathrm{sec}\right) \\
& \rho=\text { density }\left(\mathrm{gr} / \mathrm{cm}^{3}\right) \\
& c=\text { specific heat (cal/gr. deg) }
\end{aligned}
$$

The dimensions of the thermal conductivity are: cal/cm. sec. deg. In this study, the thermal diffusivity and density were measured. The specific heat is taken for the species of material constituting the sample. Differences between specific heats of the samples are small compared to differences in the other parameters.

Published thermal conductivity data for a given rock type generally show a decrease in the conductivity value with an increase in temperature at which the value is determined. A study by Woodside and Messmer (1961) gives the conductivity of six different sandstones under dry conditions and after saturation with water. These six sandstones have a range in porosity from 3 to 59 percent. A plot of the thermal conductivity of the sandstones as a function of porosity is shown in Figure 6 . The data closely fits a straight line on a semi-log plot, meaning that the conductivity is an exponential function of the porosity. Specifically, porosity bears an $e^{-x}$ relation with the conductivity. Kunii, et al (1960) published data for four different sandstones and Moiseyenko, et al (1972) give data for three other sandstones. Each set of data points approximately fits a straight line, but the lines have an increased negative slope. The differences are greatest for the rocks with low porosity (Figure 6). These studies indicate that porcsity is the major factor controlling conductivity. 


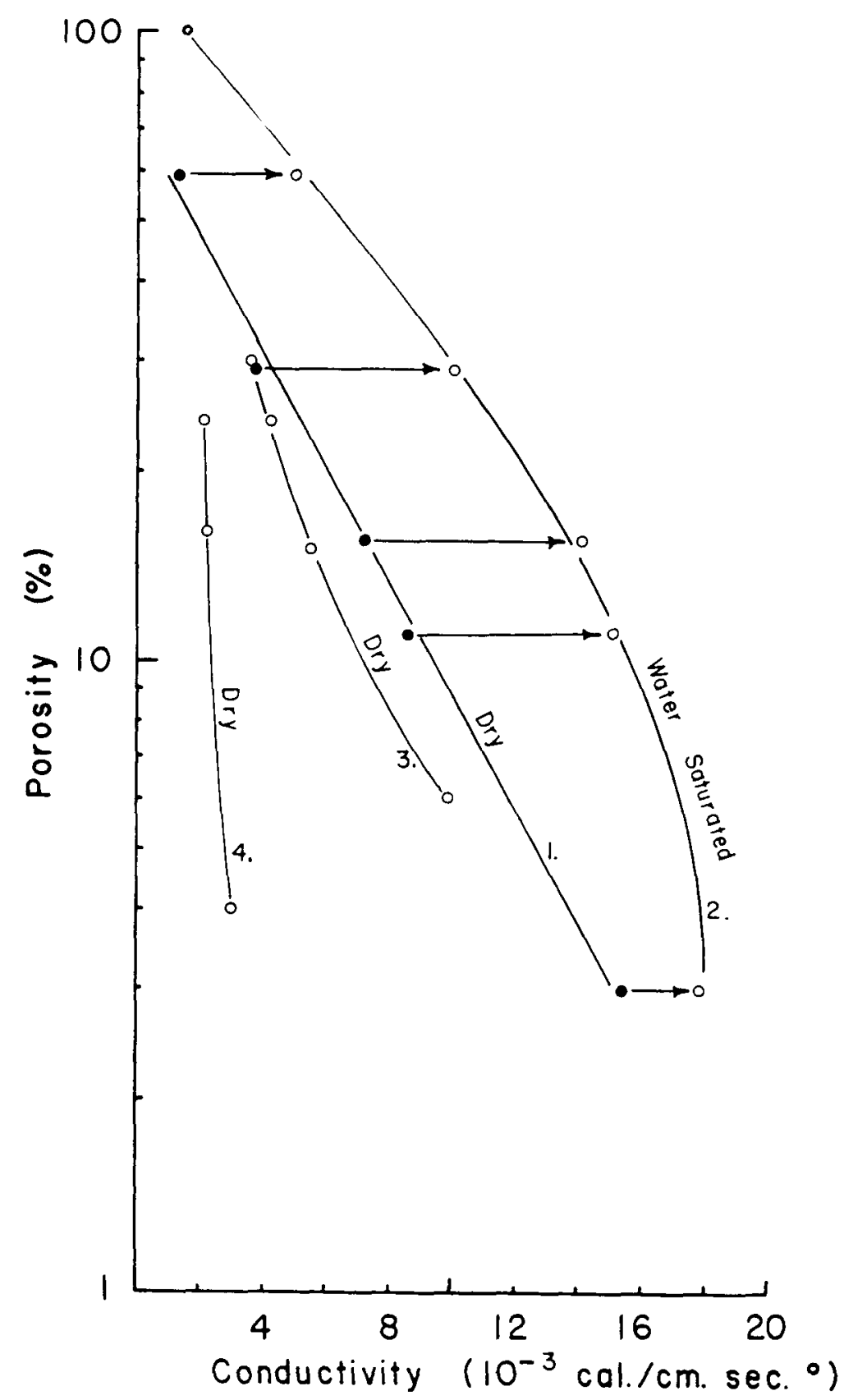

Figure 6. Thermal conductivity as a function of porosity of sandstones.

Note: Curve 1 and 2 from data by Woodside and Messmer (1961), 3 from Kunii, et al (1960), and 4 from Moiseyenko, et al (1972). 
Specific heat or heat capacity is used in the relation between thermal conductivity and thermal diffusivity. The values used are from $\mathrm{H}_{400^{\circ} \mathrm{K}}$ to $\mathrm{H}_{298^{\circ} \mathrm{K}}$ as given by Robie and Waldbaum (1968). These values were converted to cal/gr. deg., and are the following:

$$
\begin{aligned}
& \mathrm{MgO}-0.245 \mathrm{cal} / \mathrm{gr} \text {. deg. } \\
& \mathrm{Mg}(\mathrm{OH})_{2}-0.324 \\
& \mathrm{Ca}_{2} \mathrm{SiO}_{4}-0.193
\end{aligned}
$$

Data is unavaliable for montmorilionite; however, the three layer silicates muscovite, phlogopite, and talc have specific heats of $0.212,0.218$, and 0.225 , respectively. These values are similar to most silicate and oxide minerals. Consequently, a thermal conductivity of 0.22 was used for the montmorilionite.

\subsection{Procedure}

Sample cells were machined from a 3165 S block. Each sample cavity was 5/8" diameter by 1-3/4" in length and was separated from an adjacent cavity by a 1/2" wall. Each block contained seven cavities. Each cavity was sealed with a thin Teflon gasket and covered with a $1 / 4$ " thick flat plate. Thus, each cavity is cylindrical in a block that is massive relative to the dimensions of the cylinder.

Coaxial in the cylinders 15 a small diameter sheathed thermocouple, with the tip of the thermocouple central in the cylinder. This thermocouple alves the temperature of the center of the sample in the cylinder. The temperature at the perimeter of the sample is also required; this is also the temperature 
of the cylinder wall. Initially, a thermocouple was embedded in the stainless steel block close to the wall, but this was modified after the first feasibility experiments. Each sample block contained seven cylindrical sample wells. Each sample well contalned a central thermocouple. Three alternate sample wells were filled with the same sample packed to the same density. Three unpacked sample wells were used with the central thermocouple to measure the cylinder wall temperature. Thermocouples from the three samples contalning cells were connected in parallel, and the three thermocouples from the empty cells were connected in parallel. The two sets of thermocouples were then connected to yield a differential electomotive force between the empty and the sample bearing cells. With this arrangement, there are the advantages of signal averaging and measurement of differentials. The seventh cell of the block was used simply to measure the block temperature and cooling rate.

The seven-cell block becomes a massive heat sink when cooled. Deperding on the temperature range of the experiment, elther air or water was used to cool the block. Typical cooling rates were 0.05 to $0.005 \% / \mathrm{sec}$. These rates gave a sufficlent differential temperature between the center and perimeter of the sample for precise measurement, and yet the rates permitted the block, which is the heat sink, to be essentially isothermal at any moment.

The blocks with the sealed samples and cavities were heated to the desired temperature until the sample and block equilibrated. The apparatus was then cooled with the differential and the cooling rate measured. This differential temperature and cooling rate at a glven temperature are directly used in the thermal diffusivity equation. The conversion to thermal 
conductivity was made using the specific heat of the sample specles and the density of the powder in the sample cells.

\subsection{Samples}

Commercially available pelletızed Mgo was crushed and sized to $-62.5 \mu \mathrm{m}$ for the thermal experiments. This material was fine-gralned, but granular, in contrast to some flocculent Mgo powders. Dicalcium silicate was synthesized by dopıng with $\mathrm{CaNaPO}_{4}$, thus it is a solid solution variant with the composition $\left.\left.\mathrm{CaSiO}_{4}\right)_{90} \mathrm{CaNaPO}_{4}\right)_{10} 0^{\circ}$ The synthesized material had either the $\alpha^{\prime}$ or $\beta$ form, these are the forms that most readily hydrate. This synthesized material was crushed to $-62.5 \mathrm{~mm}$. Bentonite is the typical fine powdery materlal described earlier, none was pre-compacted or pelletızed to a high dersity.

The dry samples of a known weight were packed or pressed into the sample cell of known volume, from which the density was calculated. This dersity, compared to the density of the solid, gave the porosity of the sample. The density of pure bentonite is unknown because it has poor crystalinity and extensive chemical variation. A density of the bentonite used in these experiments was assumed to be 2.35 , and this value was used to calculate the porosity of the bentonite in the packed cells.

Water was added to some of the samples in different experiments to determine the thermal conductivity of the hydrous product. These samples plus the added water were held in the sample cells at elevated cemperature until the hydration reaction had gone to completion or until the water phase was exhausted. Then the thermal conductivity of the hydrous product was determined. 
With granular samples, the added water entered the interstices and the cell is sealed. However, when water is added to bentonite, the clay expands making packing and sealing impossible. To overcome this problem, water was added to the empty cell, and the water was frozen. The bentonite was then packed on top of the ice. In several thermal conductivity experiments, water was present as a separate phase. Such a mobile phase has a profound effect on heat transfer.

Thermal diffusivity was measured and thermal conductivity calculated for the following:
1. MgO
dry, packed to a density of 1.56 , sample porosity of 568
2. Doped $\mathrm{Ca}_{2} \mathrm{SiO}_{4}$
dry, packed to a density of
1.66 , sample porosity of 508
3. Bentonite
dry, packed to a density of
1.34 , sample porosity of 438
4. Bentonite
dry, packed to a density of
1.48 , sample porosity of 378
5. $\mathrm{MgO}+\mathrm{H}_{2} \mathrm{O}$
product approximately equal moles of $\mathrm{MgO}$ and $\mathrm{Mg}(\mathrm{OH})$, bulk density 1.60 , porosity 513
6. Doped $\mathrm{Ca}_{2} \mathrm{~S}_{4} \mathrm{O}_{4}+\mathrm{H}_{2} \mathrm{O}$
product hydrous calcium silicate and water as a separate phase, bulk density 1.54 , porosity $36 \%$
7. Bentonite $+\mathrm{H}_{2} \mathrm{O}$
8. Bentonite $+\mathrm{H}_{2} \mathrm{O}$ product is expanded bentonite, bulk density 1.25 , porosity 448 product is expanded bentonite, bulk density 1.23 , porosity 37 z 


\subsection{Results}

About 100 determinations were made of the thermal diffusivity of each sample as a function of temperature. A relation was developed using a least squares fit, and a 95.5 percent confidence limits were determined. The relation of thermal diffusivity to temperature for Mgo and the partially hydrated $\mathrm{MgO}$ is shown in Figure 7. The partially hydrated Mgo has slightly less porosity but nearly twice the thermal diffusivity of dry Mgo.

Thermal diffusivity for the dry varlant of $\mathrm{Ca}_{2} \mathrm{SlO}_{4}$ and the sample containing water as a separate phase is shown in Figure 8 . The relation for the water bearing sample 1 s based on 80 data points from 30 to $60 \mathrm{C}$, and the dry sample relation 1 s based on 120 data points from 30-160C. The 95.5 percent confidence limits are shown. The water bearing sample has a steeper positive relation and greater thermal diffusivity than the dry sample. Although beyond the range in which data was collected, the two trends appear likely to cross at about 15C. At temperatures below 15C, the dry sample appears likely to have the greatest thermal diffusıvity, whereas at higher temperatures the water bearing sample has the highest thermal diffusivity, as is expected on the basis of thermal conductivity of water and the porosity of the sample. There is no obvious explanation for the apparent crossing of these thermal diffusivity curves.

Bentonite was packed to different bulk densities and the thermal diffusivity determined with more than 100 data points for each sample. The bentonlte with the greatest bulk density has the greatest thermal diffusivity (Figure 9). Bentonite expanded with water and the thermal 


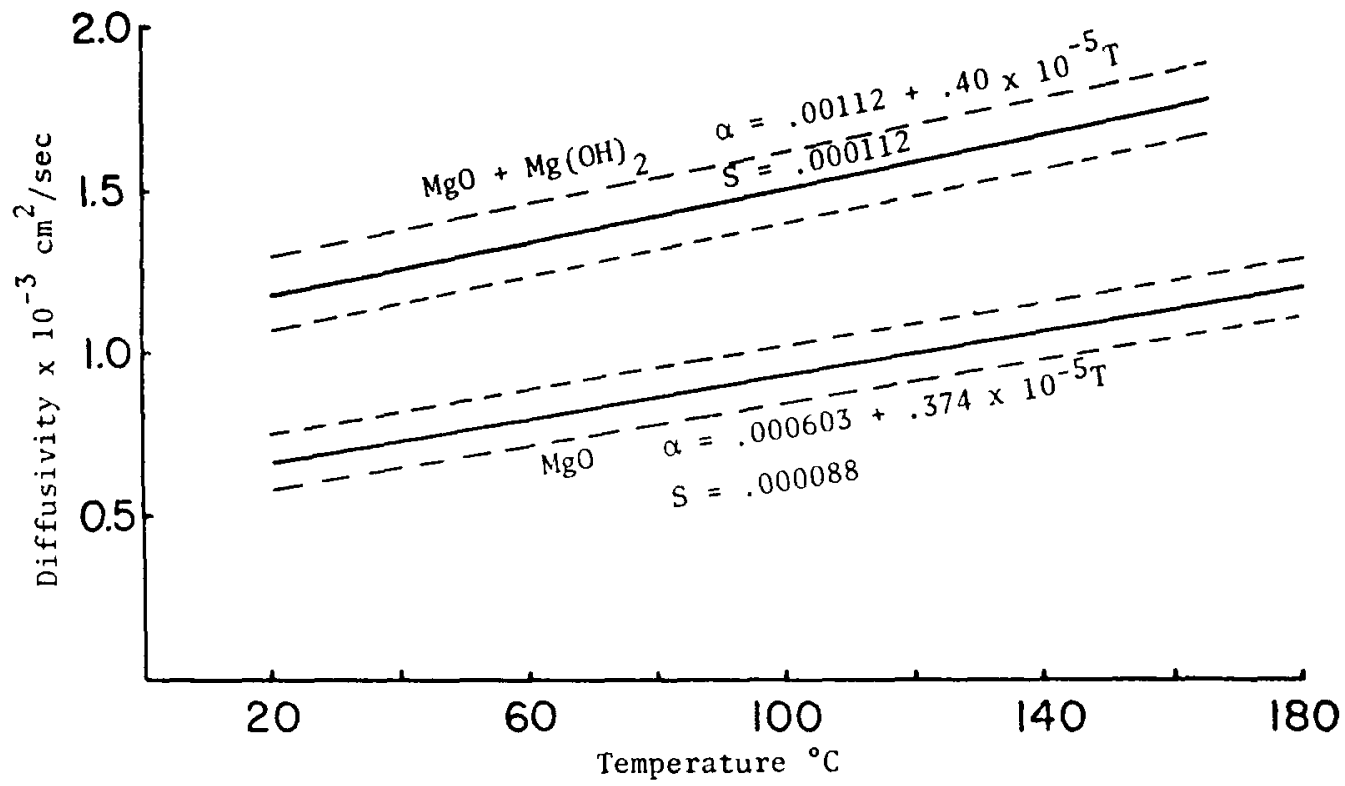

Figure 7. Thermal diffusivity $(\alpha)$ as a function of temperature for $\mathrm{MgO}$ and $\mathrm{MgO}+\mathrm{Mg}(\mathrm{OH})_{2} \cdot 95.5 \%$ confidence limits shown by dashed lines. 


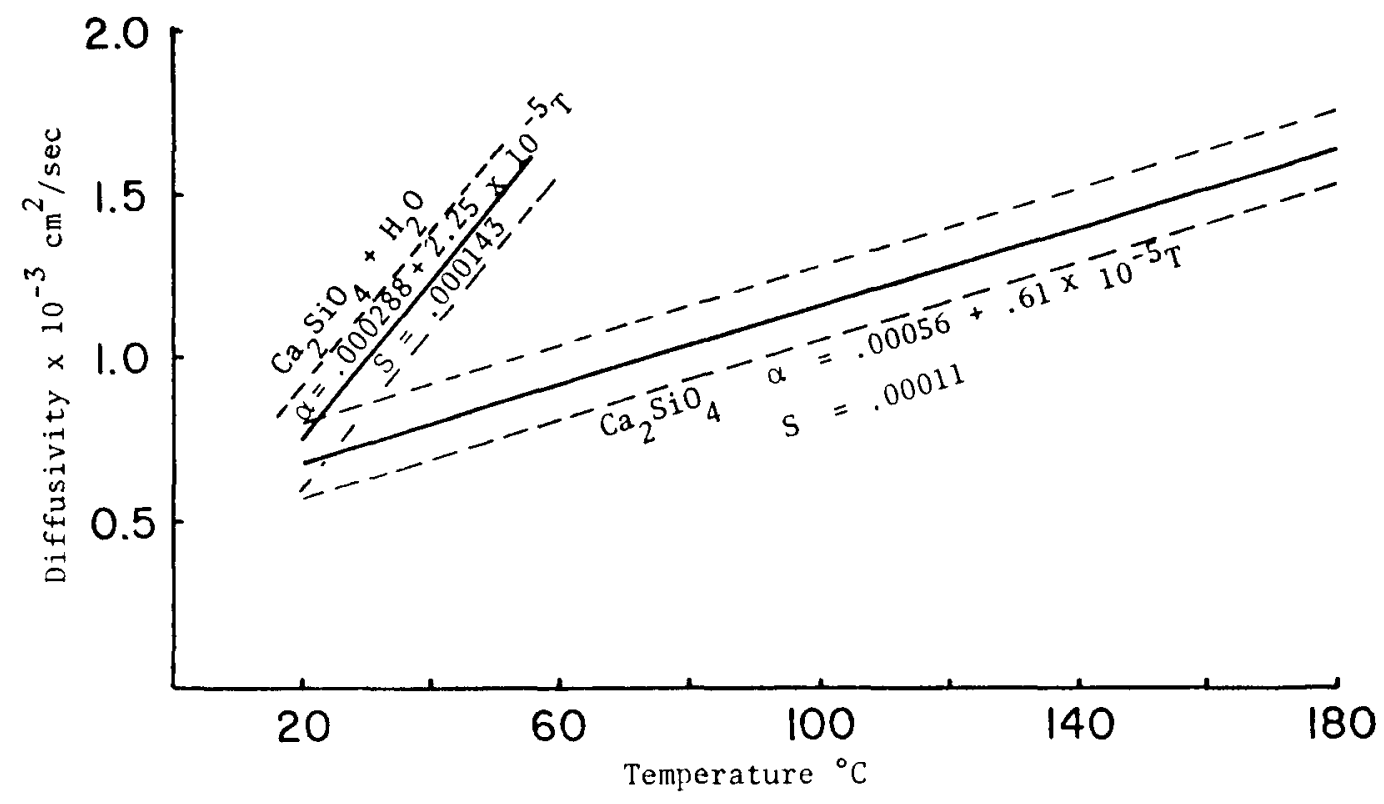

Figure 8. Thermal diffusivity $(\alpha)$ as function of temperature for doped $\mathrm{Ca}_{2} \mathrm{SiO}_{4}$ and doped $\mathrm{Ca}_{2} \mathrm{SiO}_{4}+\mathrm{H}_{2} \mathrm{O}$ as a separate phase. $95.5 \%$ confidence limits shown by dashed lines. 


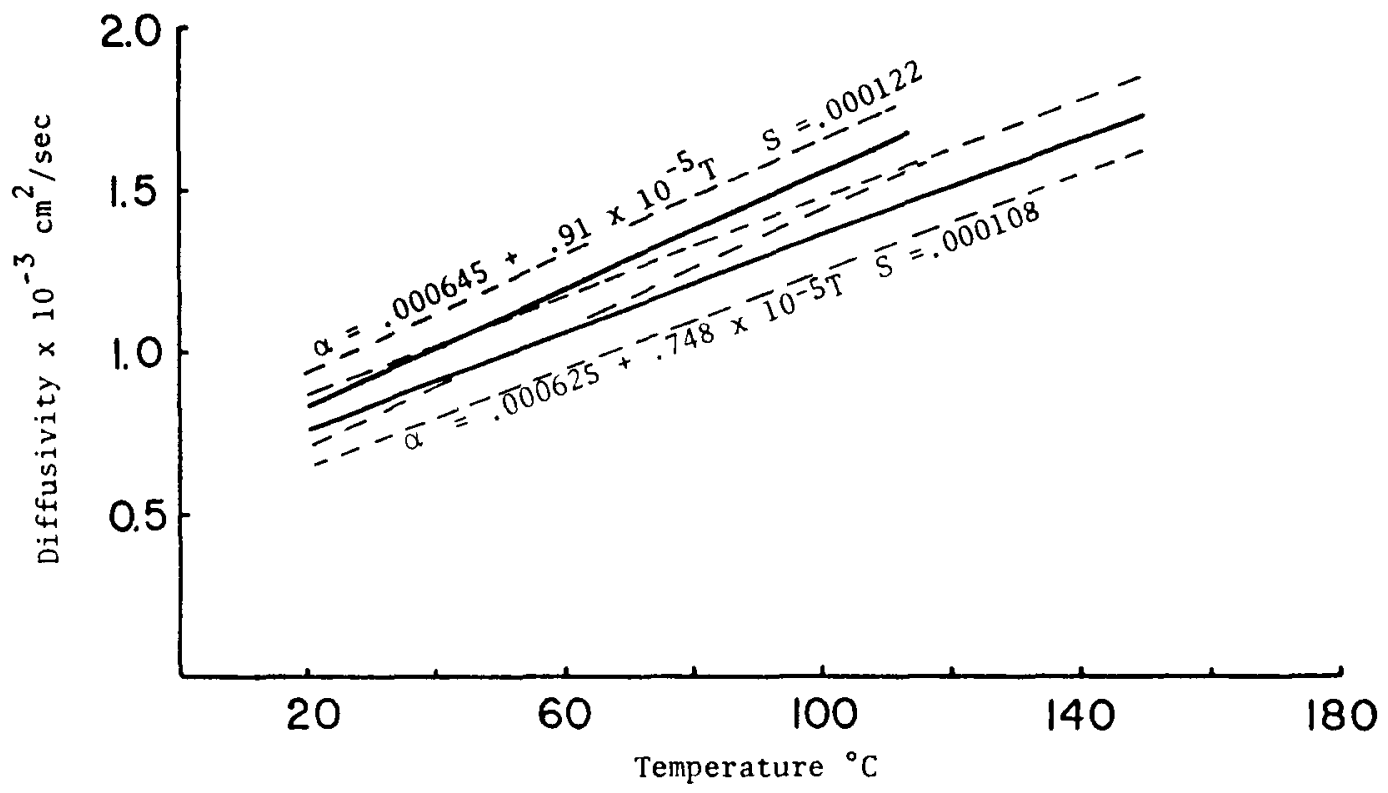

Figure 9. Thermal diffusivity of bentonite packed to a density of 1.48 (upper curve) and 1.34 (lower curve). 95.5\% confidence limits shown by the dashed lines. 
diffusivity relations for two samples, based on more than 100 data points each, is shown in Figure 10. Similar to the dicalcium silicate relations, the relations for bentonite appear to cross the relations for bentonite plus water. The bentonite plus water curve has the steepest slope for thermal diffusivity.

5.5 Thermal Conductivity values

Thermal conductivity values for the elght samples are calculated from the thermal diffusivity values at 20,60 , and $120 \mathrm{C}$ (Table 5). The diffusivity data may be used for any temperatures within the range covered by the experiments.

\subsection{Conclusions}

Thermal conductivity of materials decreases as porosity increases, as shown in Figure 6 for various sandstones. If the porous material is saturated with water, or contains water as a separate phase in the interstices, the thermal conductivity of the porous material is greatly increased. Because of these relations it is necessary to evaluate candidate backfill materials in terms of conductıvity at a given porosity. A plot of the data in Table 5 is shown in Figure 11. Mgo, as used, had the highest porosity, and tightly packed bentonite had the lowest porosity among the dry samples. This bentonite has slightly superior thermal conductivity relatıve to the more porous Mgo. However, porosity is a function of grain size distribution in the sample and especially of packing, an extrunsic variable. More effective packing reduces porosity which increases thermal conductivity. Thus, the data 


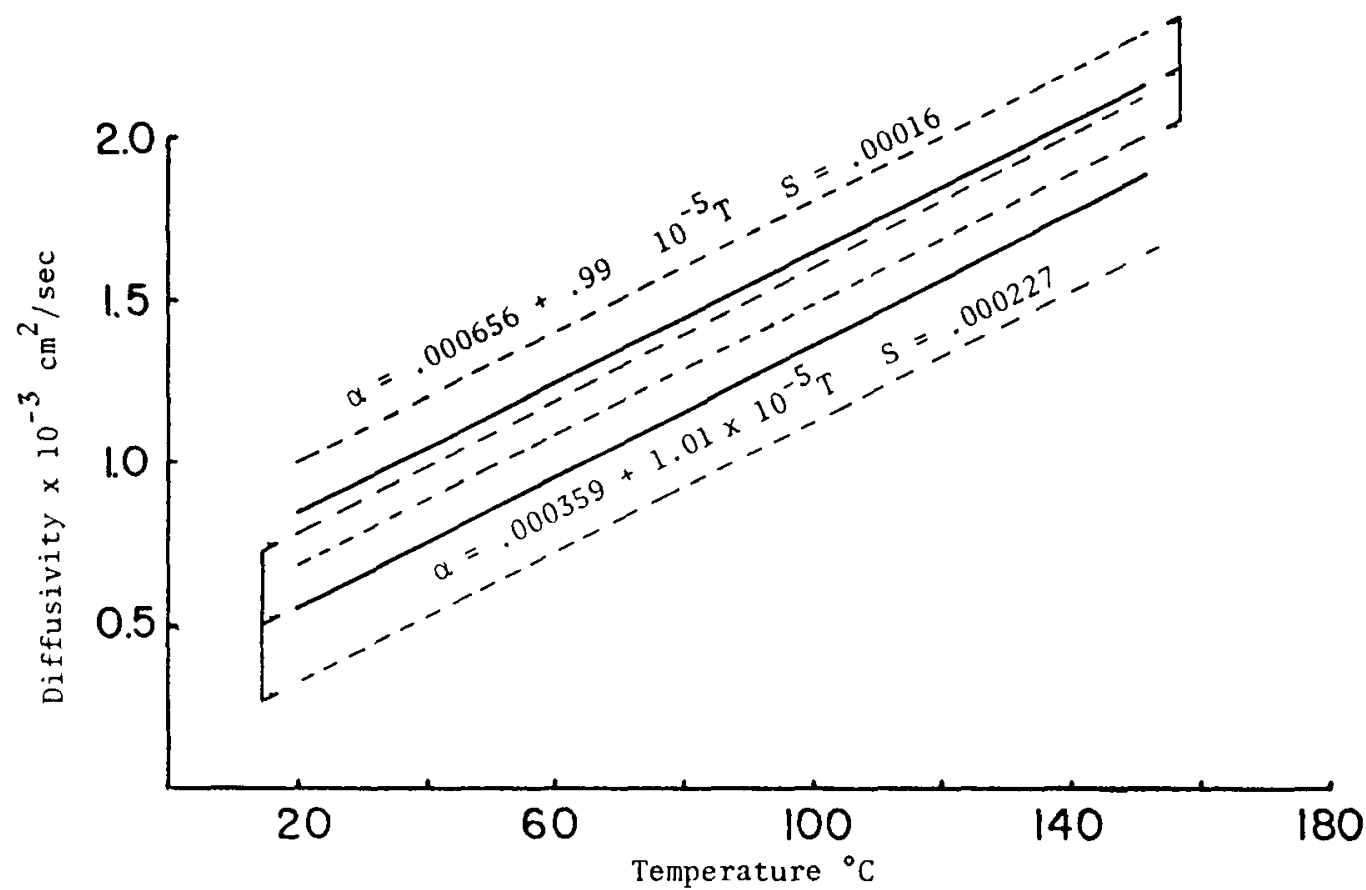

Figure 10. Thermal diffusivity as a function of temperature for bentonite + water with bulk density of 1.25 (lower curve) and 1.23 (upper curve).

Note: Brackets show 99.5\% confidence limits (dashed lines) for each curve. Compare slopes to Figure 9. 
TABLE 5

Thermal Conductivity

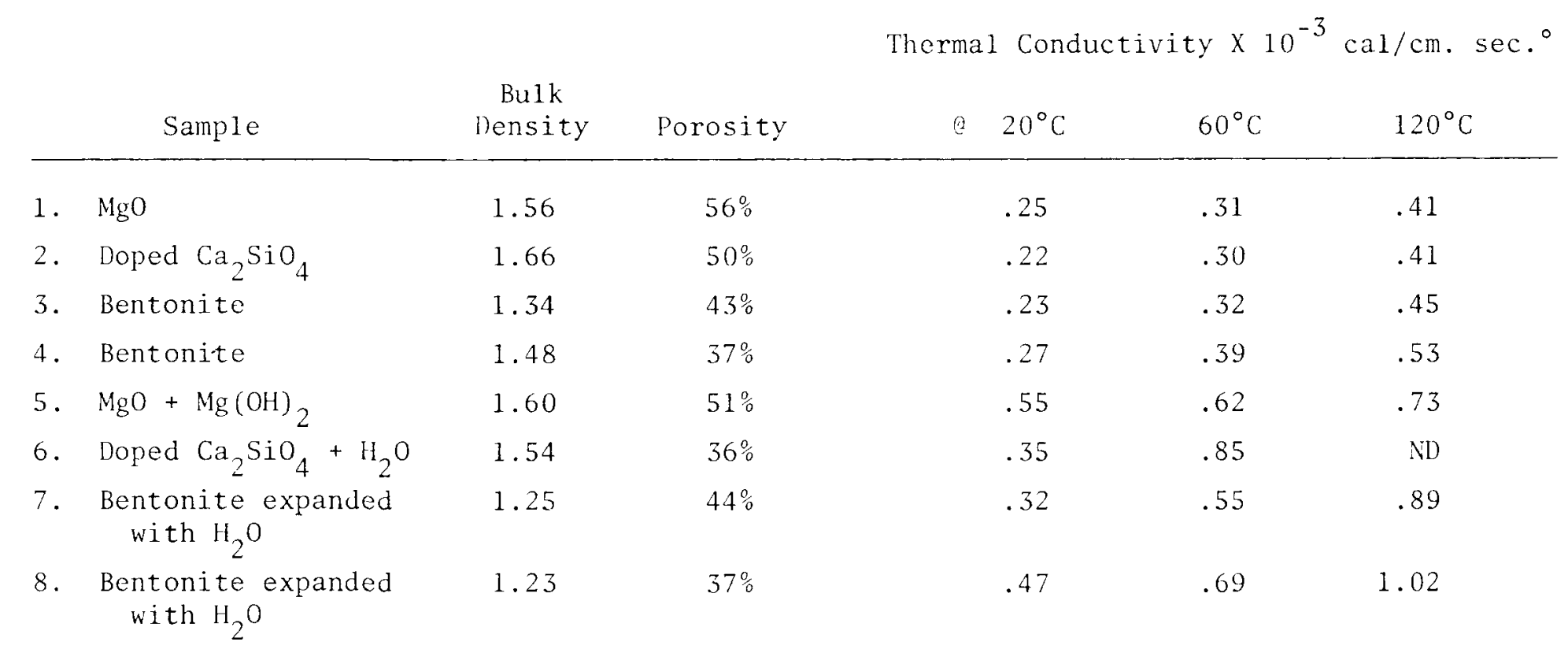




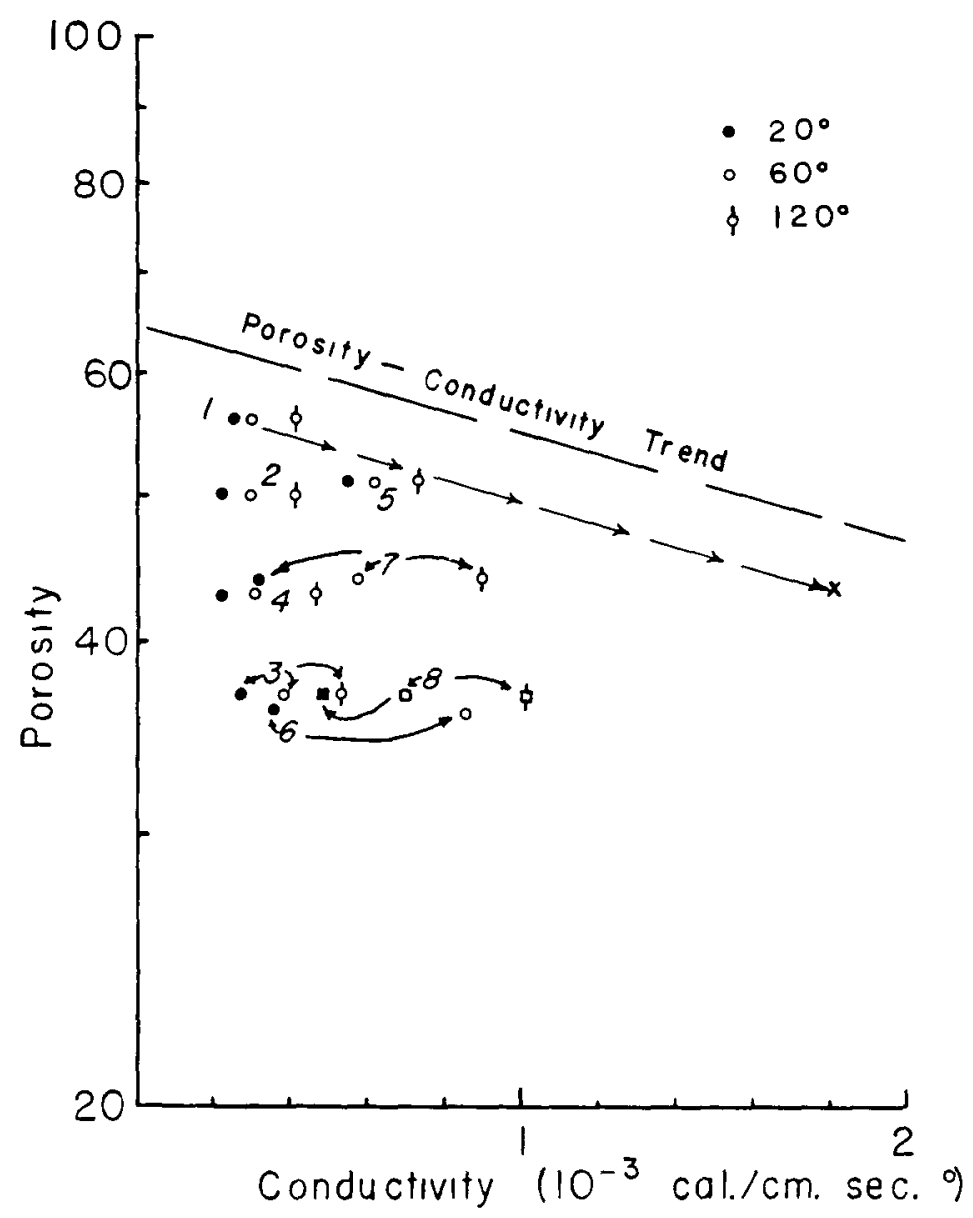

Figure 11. Thermal conductivity of candidate overpack materials as a function of porosity.

Note: Number keyed to sample numbers in text. Arrows indicate trend of thermal conductivity with decreased porosity. 
must be evaluated in view of the porosity. Fortunately, the effect of pcrcsity has been established, as shown in Figure 6, and the trend based on the data by woodside, et al (19EI) is showr. in Figure 11. This trend was used because it is based on more data points than that by Kunll, et al or Molseyerkc, et al, and it covers the porosity range considered in the present study.

MaC packed with 56 percent porosity has a thermal conductivty of $0.25 \times 10^{-3} \mathrm{cal} / \mathrm{cm}$. sec. ${ }^{\circ}$. If the porosity is reduced the conductivity increases approximately in accord with the trend shown by woodside, et al (1961). For example, if the porosity of the Mgo is reduced to 43 percent by tighter packing, the conductivity would be shifted, as showr by the arrow in Figure 11, to a new value of about $1.75 \times 10^{-3} \mathrm{cal} / \mathrm{cm}$. sec. ${ }^{\circ}$. Because of a similar porosity, this projected value can be related to dry bentonite. The data show Mgo to be superior to bentonite in thermal conductivity at a given porosity. In fact, among the materials tested and adjusted to a common porosity, Mgo shows the superior conductivity.

The addition of water to the system increases the thermal conductivity. With some materials this is partly the result of the hydrous product having a greater volume than its anhydrous predecessor, and therefore, with hydration, the porosity is decreased. Water present as a discrete phase reduces porosity and is a moblle material of high thermal properties; therefore, thermal conductivity of a wet material is superzor to that of dry material. 


\subsection{SUMMARY AND CONCLUSIONS}

Backfiil materiais should be a desiccant, sorb any released radioisotopes, and preserve the integrity of the system. The materials must have adequate stablilty as reactants and products and they must have appropriate thermal conductivity. Mgo, dicaicium silicate, and bentonite are candidate backfili materlals. The purpose of this research was to determine the rate and products of reaction and the thermal conductivity of the materials.

The rate of hydration of granular MgO as a function of temperature and graln slze was determined. At $150 \mathrm{C}$ wth a water vapor pressure of 4.6 atmospheres MgO completely hyarated to $\mathrm{Mg}(\mathrm{OH})_{2} 1 \mathrm{n}$ less than 10 hours. At $60 \mathrm{C}$ extensive hydration required about 100 hours, and at $20 \mathrm{C}$ extensive hydration required more than 1000 hours. Graın size and therefore surface area had the greatest effect for experiments at $60 \mathrm{c}$. From this data the extent of hydration for Mgo with a given surface area at a given temperature and tıme can be determined.

A chemical variant of alcalcium silucate with the composition $\left.\left.\mathrm{Ca}_{2} \mathrm{~S}_{1} \mathrm{O}_{4}\right)_{90} \mathrm{CaNaPO}_{4}\right)_{10}$ was syntheszzed. The compound had the $B$ or $\alpha^{\prime}$ form, and this material was reacted with water in a manner similar to the $\mathrm{MgO}$. The extent and rate of reaction of the doped dicalcium silicate is markedly inferior to MgO. The hydration product has a cementitious nature, but it lacks moderate temperature stability.

Bentonite was reacted with water and brine to determine the nature and stablity of the reaction products. Bentonite is known to expand with water and because of enormous surface area it readily undergoes ion exchange. Unfortunately, bentonite lacks moderate temperature 
stability. Thus, bentorilte may be a desiccant at low temperature and sorb lors, but it becomes a water source at increased temperature as a result of its owr decomposition.

Bentonite slowly heated begins to lose water at $30 \mathrm{C}$ and this loss continues to 105C. This welght loss causes a decrease in volume which Is an increase in porosity. The vapor pressure of water from the NBT-6a type brine was sufficiently low to cause a desiccation of the bentonite, agair increasing the porosity.

The NBT-6a type brine contains high concentrations of alkaline earth and alkalı chiorlde salts. The magnesium lons of the brine reacted with the bentonite. DTA, TGA, and X-ray diffraction indicate that this reaction product is a vermiculite. Such a reaction involves Ion exchange and migration of magnesium ions to an octahedral site, a process termed "place exchange". Vermiculite contains more water than unexpanded bentorite, and it is stable to a slightly higher temperature. The lon exchange with the brine will clearly affect the radiolsotope ion exchange.

Thermal diffusivity and thermal conductivity determinations on Mgo, dicalcium silicate, bentonite, and hydrous reaction products showed the sensitivity of the determinations to sample porosity. Thermal conductivity values for the different materials at 20,60 , and $120 \mathrm{C}$ with porosity ranging from 36 to 56 percent yielded values of $0.22 \times 10^{-3}$ to $1.02 \times 10^{-3} \mathrm{cal} .1 \mathrm{~cm}$. sec. ${ }^{\circ}$. Increased thermal conductivity is found with decreased porosity and increased hydration.

There is a small increase in thermal conductivity with increased temperature, in contrast to rocks that typically show decreased thermal 
conductivity wath increased temperature. The increased thermal conductivity with increased temperature is also reported in the Sandia National Laboratories quarterly report concerning the thermal conductivity of bentonite. The increased conductivity may result from thermal expansion of the contalned or jacketed powder ylelding better grain to grain contact.

If porosity is considered a extrinsic variable, controlled by the grain size and installation techniques, Mgo is the superior material also in regard to thermal conductivity. In practice, the thermal conducitivity of $\mathrm{MgO}$ can be further improved by installing and packing of arhydrous material and then controlling in situ hydration. Such a practice would reduce the porosity and increase the thermal conductivity.

Mgo is found to be superior to bentonite and dicalcium silicate in regard to desiccant capacity, thermal stability of the hydrous product, and thermal conductivity. 
References

Fleischer, M., 1975. Glossary of Mineral Species, Mineralogical Record, Ir.c., Mà.

Kun11, D., and J. M. Smıth, 1960. "Heat Transfer Characteristıcs of Porous Rocks", Journal of A I Ch E., 6:1, PP. 71-8.

Molseyenko, U. I., L. S. Sokolova, and V. Ye. Istomin, 1971. Electrical and Thermal Properties of Rocks, Nauka Press. English Translation: NASA TT F-671 (1972).

Roble, R. A., and D. R. Waldbaum, 1968. "Thermodynamic Properties of Minerals and Related Substances at $298.15^{\circ} \mathrm{K}$ and one Atmosphere Pressure and at Higher Temperatures", U.S. Geological Survey Bulletin 1259 .

Simpson, D. F., 1980. Desiccant Materlals Screening for Backfill in a SaIt Repository, ONWI-214, prepared for Office of Nuciear Waste Isolation, Battelle Memorial Institute, Columbus, $\mathrm{OH}$.

Theng, K. G., 1974. The Chemsstry of Clay-Organic Reactions, Halstead Press, John Wiley, N.Y.

Woodside, W., and J. H. Messmer, 1961. "Therma1 Conductivity of Porous Media, II. Consolidated Rocks", Journal of App1ied Physics, Vo1. 32, No. 9, pp. 1699-1706. 



\section{DISTRIBUTION LIST}

ACRES AMERICAN INC

R STRUBLE

ALLIED GENERAL NUCLEAR SERVICES

$K$ I ANDERSON

P F HIGHBERGER

$M$ A KOLB

ALLIS-CHALMERS GARRICK I SOLOVEY

AMERICAN NUCLEAR INSURERS DOTTIE SHERMAN

APPLIED MECHANICS INC GRAHAM G MUSTOE JOHN R WILLIAMS

ARGONNE NATIONAL LABORATORY DAVID F FENSTER

SHERMAN M FRIED

I HOWARD KITTEL

MARTIN SEITZ

MARTIN I STEINDLER

W 5 WHITE

ARINC RESEARCH CORP

H P HIMPLER

ARTHUR D. LITTLE INC

AVIVA BRECHER

CHARLES R HADLOCK

ATOMIC ENERGY CONTROL BOARD I L WALLACH

ATOMIC ENERGY COUNCII KUO-YUEH LIU

ATOMIC ENERGY OF CANADA LTD $M O$ LUKE

ANN QUINN

F P SARGENT

ATOMIC ENERGY RESEARCH ESTABLISHMENT $R$ L NELSON

ATOMIC INDUSTRIAL FORUM INC EMANUEL GORDON

BABCOCK \& WIL COX INFORMATION SERVICES

BALL ASSOCIATES LTD DOUGLAS BALL

BATTELLE COLUMBUS DIVISION JEFFREY L MEANS

NEIL E MILLER THOMASM TRAINER KENNETH R YATES

BECHTEL GROUP INC THOMAS S BAER DON B CRANDALL

R C LOVINGTON

$N$ A NORMAN

RICHARD I TOSETTI

BENDIX FIELD ENGINEERING CORP JOHN C PACER

BHABHA ATOMIC RESEARCH CENTRE $\checkmark$ SUKUMORAN $K$ T THOMAS

BLACK \& VEATCH M JOHN ROBINSON

BRITISH NUCLEAR FUELS LTD R S WILKS

BROOKHAVEN NATIONAL LABORATORY

M S DAVIS

SANDRA G LANE

P W LEVY

SAMUEL $\checkmark$ PANNO

PETER SOO

HELEN TODOSOW (2)

BUNDESMINISTERIUM FUR FORSCHUNG ROLF-PETER RANDL
CALIFORNIA DEPT OF CONSERVATION PERRY AMIMITO

CALIFORNIA DEPI OF HEALTH SERVICES BEVERLEE MYERS

CALIFORNIA INSTITUTE OF TECHNOLOGY LEON T SILVER

CAPITAL AREA GROUND WATER

CONSERVATION COMMISSION

A N TURCAN IR

CAPITAL UNIVERSITY

VICTOR M SHOWALTER

CARNEGIE-MELLON UNIVERSITY STEPHEN G ZEMBA

CASTLE VALLEY ORCHARDS CARL ANDERSON

CAYUGA LAKE CONSERVATION ASSOCIATION INC D S KIEFER

CENTRAL WASHINGTON UNIVERSITY I R HINTHORNE

CENTRE D ETUDE DE L ENERGIE NUCLEAIRE RENE HEREMANS

CHALMERS UNIVERSITY OF TECHNOLOGY BERT ALLARD

CHEM-NUCLEAR SYSIEMS INC ROBIN L DEAL

CITIZENS ASSOCIATION FOR SOUND ENERGY JUANITA ELLIS

COLUMBIA UNIVERSITY HUBERT STALDIGEL

CONNECTICUT GOVERNORS OFFICE MARYM HART

CONSERVATION COUNCIL OF NORTH

CAROLINA

JANE SHARP

CONVERSE WARD A $M$ HALE

CORNELL UNIVERSITY

JOHN BIRD ROBERT POHL

COUNCIL ON ECONOMIC PRIORITIES MARVIN RESNIKOFF

CYGNA ENERGY SERVICES DONALD GARDNER

DAMES \& MOORE RON KEAR O L OZTUNOU

DAPPOLONIA CONSULTING ENGINEERS INC LISA K DONOHUE ABBY FORREST AMIRA HAMDY PETER C KELSALL CARL E SCHUBERT

DAWCON MANAGEMENT CONSULTING SERVICE DAVID A WEBSTER

DELAWARE CUSTOM MATERIEL INC HOWARD NOVITCH

DRAVO ENGINEERS AND CONSTRUCTORS KEN BEALL

DUKE UNIVERSITY THOMAS DAVIS

E.R. JOHNSON ASSOCIATES INC E R JOHNSON G L JOHNSON

EAST COMPANY INC RAYMOND PEREZ

EAST TENNESSEE STAIE UNIVERSITY ALBERT F IGLAR

EBASCO SERVICES INC ZUBAIR SALEEM
EDISON ELECTRIC INSTITUTE R E L STANFORD

EDS NUCLEAR INC

C SUNDARARAJAN

EG \& G IDAHO INC

GEORGE B LEVIN

$M$ D MCCORMACK

T H SMITH

RICHARD TALLMAN

ELECTROWATT ENGINEERING SERVICE H N PATAK

ELSAM

$$
A \vee j O S H I
$$

EMBASSY OF THE UNITED SIATES (SWEDEN) MAUD LI HAIJLEN-RYLANDER

ENERGY FUELS NUCLEAR INC DON M PILLMORE

ENERGY RESEARCH LABORATORY HITACHI INC

MAKOTO KIKUCHI

ENVIRONMENT CANADA CLAUDE BARRAUD

ENVIRONMENTAL POLICY INSTITUTE DAVID M BERICK FRED MILLAR

ENVIROSPHERE COMPANY BOB HAINES

ERTEC WESTERN INC KENNETH WILSON

EXXON NUCLEAR IDAHO COMPANY INC

D L. CONDOTTA

W B KERR

GARY WAYMIRE

F.B.A.B.

OTTO BROZEN

FENIX \& SCISSON INC JOSE A MACHADO

FLORIDA DEPT OF ENVIRONMENTAL

REGULATION

HAMILTON OVEN

FLORIDA INSTITUTE OF TECHNOLOGY JOSEPH A ANGELO, JR

FLORIDA STATE UNIVERSITY JOSEPHF DONOGHUE

FLUOR ADVANCED TECHNOLOGY DIVISION JOAN $V$ MCCURRY

FLUOR ENGINEFRS \& CONSTRUCTORS INC RAYMOND I DUGAL

FORD, BACON \& DAVIS UTAH INC PRESTON H HUNTER BURTON I THAMER

FOSTER-MILLER ASSOCIATES INC NORBERT PAAS

FREIE UNIVERSITAET BERLIN HANSKARL BRUEHL

FRIENDS OF THE EARTH LOUIS BUCKLIN

GENERAL ATOMIC COMPANY ROBERT M BURGOYNE ROBERT I CAMPANA

GEO/RESOURCE CONSULTANTS INC ALVIN K JOE, JR

GEOLOGICAL SURVEY OF CANADA JOHN SCOTT

GEOLOGICAL SURVEY OF DENMARK L F ANDERSEN

GEORGIA INSTITUTE OF TECHNOLOGY ALFRED SCHNEIDER CHARLESE WEAVER

CEOTECHNICAL ENGINEERS INC RICHARD W TURNBULI. 
GEOTRANS

JAMES MERCER

GERMANTOWN FRIENDS SCHOOI HERB BASSOW

GESELLSCHAFT F. STRAHLEN $U$. UMWELTFORSCHUNG M.B.H.

WOLFGANG BODE

HANS W LEVI

GIBBS \& HILL INC ROBERT PRIETO

GILBERT/COMMONWEALTH IERRY L ELLIS

GOLDER ASSOCIATES

ELIZABETH FISENHOOD

LAWRENCE A WHITE

CLEMENT M K YUEN

GTC GEOLOGIC IESTING CONSULTANTS LTD JOHN F PICKENS

H \& R IECHNICAL ASSOCIATES INC WILLIAM R RHYNE

HAHN-MEITNER-INSTITUT FUR

KERNFORSCHUNG BERLIN KLAUS ECKART MAASS

HANFORD ENGINEERING DEVELOPMENT

LABORATORY

ROBERT EINZIGER

R L KNECHT

W E ROAKE

HARDING LAWSON ASSOCIATES

FRANK C KRESSF

HARVARD UNIVERSITY

DADE W MOELLER

RAYMOND SIEVER

HIRAM COLLEGE IAMES W COWDEN

HOUGH-NORWOOD HEALTH CARE CENTER GEORGE H BROWN MD

IDAHO BUREAU OF MINES AND GEOLOGY EARL H BENNETT CHARLES R KNOWLES

IMPERIAL COLLEGE OF SCIENCE AND

TECHNOLOGY

B K ATKINSON

INSTITUT FUR TIEFLAGERUNG

WERNT BREWITZ

$H$ GIES

KLAUS KUHN

E R SOLTER

PETER UERPMANN

INSTITUTE FOR CHEMICAL IECHNOLOGY REINHARD ODO

INSTITUTE OF GEOLOGICAL SCIENCES NEIL A CHAPMAN

INSTIIUTE OF RADIATION PROTECTION KAI JAKOBSSON

INTERA ENVIRONMENTAL CONSULTANTS INC LARRY RICKERTSEN ROBERT WILEMS

INTERNATIONAL ATOMIC ENERGY AGENCY EVERETT R IRISH FRANK A OHARA

INTERNATIONAL ENERGY ASSOCIATES LTD BL YTHE K LYONS

INTERNATIONAL ENERGY SYSTEMS CORP IOHN A BOWLES

INTERNATIONAL ENGINEERING COMPANY INC

TERRY L STEINBORN

MAX ZASLAWSKY

INTERNATIONAL RESEARCH AND

EVALUATION

$R$ DANFORD
IOWA STATE COMMERCE COMMISSION ROBERT J BUCKLEY

IOWA STATE UNIVERSITY

I F MCCLELLAND

IRT CORP

J STOKES

ISTITUTO SPERIMENTALE MODELLI E

STRUTTURE S.P.A.

F GERA

J.F.T. AGAPITO \& ASSOCIATES INC

MICHAEL P HARDY

JACKSON STATE UNIVERSITY ESTUS SMITH

JAPAN ATOMIC ENERGY RESEARCH INSTITUTE TARO ITO

HARUTO NAKAMURA

JGC CORPORATION

MASAHIKO MAKINO

JORDAN GORRILL ASSOCIATES JOHND TEWHEY

KAISER ENGINEERS INC

W I DODSON

J $S$ RITCHIE

KANSAS DEPT OF HEALTH AND

ENVIRONMENT

GERALD W ALLEY

KBS

LARS B NILSSON

KEULER WREATH ASSOCIATES

FRANK WREATH

KERNFORSCHUNGSZENTRUM KARLSRUHE GMBH

K D CLOSS

R KOSTER

HORST PENTINGHAUS

KIHN ASSOCIATES HARRY KIHN

KLM ENGINEERING INC B GEORGE KNIAZEWYCZ

KOREA INSTITUTE OF ENERGY AND RESOURCES (KIER) CHOO SEUNG HWAN

KYOTO UNIVERSITY YORITERU INOUE

LABORATOIRE RENE BERNAS I C DRAN

LAWRENCE BERKELFY LABORATORY

JOHN A APPS

THOMAS DOE

NORMAN M EDELSTEIN

BRIAN KANEHIRO

I WANG

LAWRENCE LIVERMORE NATIONAL

LABORATORY

LYNDEN B BALLOL

DANA ISHERWOOD

D D JACKSON

LAWRENCE D RAMSPOTT (2)

FRANK ROGUE

W G SUTCLIFFE

TECHNICAL INFORMATION DEPARTMENT $L-53$

RICHARD VAN KONYNENBURC

LEHIGH UNIVERSITY

D R SIMPSON

LOS ALAMOS NATIONAL LABORATORY

ERNEST A BRYANT

GEORGE A COWAN

BRUCER ERDAL

CLAUDE HERRICK

$K$ K 5 PILLAY

KURT WOLFSBERG
LOS ALAMOS TECHNICAL ASSOCIATES INC $R$ J KINGSBURY

LOS ANGELES PIERCE COLLEGE

SIGMUND P HARRIS

LOUISIANA DEPT OF TRANSPORTATION \& DEVELOPMENT

GEORGF H CRAMER $\|$

IOUISIANA GEOLOGICAL SURVEY SYED HAQUE

LOUISIANA NUCLEAR ENERGY DIVISION

L HALL BOHLINGER (3)

LOUISIANA TECH UNIVERSITY

LIBRARY

NORMAN WITRIAL

LOUISIANA TECHNICAL NUCLEAR CENTER R H THOMPSON

MASSACHUSETIS INSTITUTE OF

TECHNOLOGY

JOHN DEUTCH

TED GREENWOOD

RICHARD K LESTER

MARSHA LEVINE

MCDERMOTT INC

KAREN L FURLOW

MCMASTER UNIVERSITY

L W SHEMILT

MEMBERS OF THE GENERAL PUBLIC

DAVID H BOLTZ

JAMES BOYD

WILLIAM E CONAWAY

STEVE CONEWAY

RALPH DILLER

BRIAN DOMBROWSKI

DANNELLE D DUDEK

DOROTHY FORD

RICHARD L FOUKE

BARRETT R FRITZ

SHIRLEYM GIFFORD

DARYL GLAMANN

OSWAID H GREAGER

DOUGLASH GREENLEE

HAROLD L IAMES

THOMAS H LANGEVIN

D C IANGSTAFF

DAWID LYLE

MAX MCDOWELL

A ALAN MOGHISSI

ALAN D PASTERNAK

SHAILER 5 PHILBRICK

ROGER E POWERS

PAUL SHEWMON

M I SZULINSKI

GORDON THOMPSON

A E WASSERBACH

IIMMY L WHITE

MEMORIAL UNIVERSITY OF

NEWFOUNDLAND

JOHN E GALE

MICHAEL BAKER, JR. INC

C I TOUHILL

MICHIGAN DEPT OF PUBLIC MEALTH

DON VAN FAROWE

MICHIGAN DISTRICT HEALTH DEPT NO 4 EDGAR KREFT

MICHIGAN TECHNOLOGICAL UNIVERSITY GARYL DOWNEY

MINERALOGICAL SOCIETY OF AMERICA EDWIN ROEDDER

MISSISSIPPI ATTORNEY GENERAIS OFFICE MACK CAMERON 
MISSISSIPPI CITIZENS AGAINST NUCLEAR DISPOSAL

STANLEY DEAN FLINT

MISSISSIPPI DEPT OF ENERGY AND

TRANSPORTATION

JOHN W GREEN (3)

MISSISSIPPI DEPT OF NATURAL RESOURCES

CHARLES L BLALOCK

MISSISSIPPI DEPT OF WILDLJFE

CONSERVATION

JOSEPH W JACOB JR

MISSISSIPPI EMERGENCY MANAGEMENT AGENCY

JAMES E MAHER

MISSISSIPPI STATE BOARD OF HEALTH EDDIE S FUENTE

J WARREN GREEN

MISSISSIPPI STATE HOUSE OF

REPRESENTATIVES

HILLMAN TEROME FRAZIER

JERRY OKEEFE

MITRE CORP

LESTER A ETTLINGER

MITSUBISHI METAL CORP TATSUO ARIMA

MOBAY CHEMICAL CORP KENNETH H HASHIMOTO

NASA JOHNSON SPACE CENTER MICHAEL R HELFERT

NATIONAL ACADEMY OF SCIENCES JOHN T HOLLOWAY PETER B MYERS

NATIONAL ATOMIC MUSEUM GWEN SCHREINER

NATIONAL BOARD FOR SPENT NUCLEAR

FUEL, KARNBRANSLENAMDEN NILS RYDELL

NATIONAL BUREAU OF STANDARDS RILEYM CHUNG WILLIAM P REED

NATIONALE GENOSSENSCHAFT FUR DIE

LAGERUNG RADIOAKTIVER ABFALLE MARLIES KUHN

NATURAL RESOURCES DEFENSE COUNCIL THOMAS B COCHRAN

NEVADA DEPT OF ENERGY ROBERT R LOUX

NEW ENGLAND NUCLEAR CORP KERRY BENNERT CHARLES B KILLIAN

NEW JERSEY DEPT OF ENVIRONMENTAL PROTECTION JEANETTE ENG

NEW MEXICO ENVIRONMENTAL FVALUATION GROUP ROBERT H NEILL

NEW YORK DEPT OF HEALTH DAVID AXELROD MD

NEW YORK STATE ENERGY OFFICE JOHN P SPATH (15)

NEW YORK STATE ENVIRONMENTAL

FACILITIES CORP

PICKETT T SIMPSON

NEW YORK STATE ERDA JOHN C DEMPSEY

NEW YORK STATE GEOLOGICAL SURVEY ROBERT H FAKUNDINY

NEW YORK STATE PUBLIC SERVICE COMMISSION

FRED HAAG
NEW YORK UNIVERSITY MEDICAL CENTER MERRIL EISENBLD

NEYER, TISEO, \& HINDO LTD KALR HINDO

NIEDERSACHSISCHES SOZIALMINISTERIUM HORST SCHNEIDER

NORTH CAROLINA DEPT OF NATURAL

RESOURCES \& COMMUNITY DEVELOPMENT

NORTH DAKOTA GEOLOGICAL SURVEY DON L HALVORSON

NORTH ILLINOIS UNIVERSITY B VON ZELLEN

NORTHEAST FOUR COUNTY REGIONAL PLANNING \& DEVELOPMENT ORGANIZATION JOHN C PIERSON

NORTHWESTERN UNIVERSITY BERNARD I WOOD

NTR GOVERNMENT SERVICES THOMAS $V$ REYNOLDS

NUCLEAR ASSURANCE CORP ANDREW I FRANKEL JOHN $V$ HOUSTON JEAN RION

NUCLEAR ENERGY AGENCY/OECD ANTHONY MULLER

NUCLEAR INFORMATION AND RESOURCE SERVICE GARY HZKOWITL

NUCLEAR SAFETY RESEARCH ASSOCIATION KAZUMORI MATSUO

NUCLEAR SYSTEMS ASSOCIATES INC CHARLES I DIVONA

NUCLEAR WASTE WATCHERS HELEN LETARTE

NUS CORP

W G BELTER

BARRY N NAFT

DOLGLAS D ORVIS DOUGLAS W TONKAY

NUTECH ENGINEERS INC ALFRED SL GARMAN PAUL C SLN

NWT CORP $W$ L PEARL

OAK RIDGE NATIONAL LABORATORY

I O BIOMEKE

H C CLAIBORNE

ALLEN G CROFF

LESLIE R DOLE

JOHN T ENSMINGER

CATHYS FORE

DAVIDC KOCHER

ELLEN D SMITH

STEPHEN S STOW

OFFICE OF NWTS INTEGRATION ROBERT E HEINEMAN HARRY $W$ SMEDES

OHIO ENVIRONMENTAL COUNCIL STEPHEN H SEDAM

ONTARIO HYDRO

$R$ W BARNES

I A CHADHA

K A CORNELL

C F LEE

ONTARIO RESEARCH FOUNDATION LYDIAM LUCKEVICH

OPEN EARTH PETER I SMITH

OREGON DEPT OF ENERGY DONALD W GODARD
OREGON STATE UNIVERSITY BRIAN DODD

ORGANISATION FOR ECONOMIC COOPERATION AND DEVELOPMENT I P OLIVIER

OTHA INC IOSEPH A LIEBERMAN

PACIFIC GAS AND ELECTRIC COMPANY ADRIAN C SMITH JR

PACIFIC NORTHWEST LABORATORY

W F BONNER

DON I BRADLEY

H C BURKHOLDER

L L CLARK

FLOYD N HODGES

J $H$ JARRETT

MAXR KREITER

DONALDE LARSON

I E MENDEL

R WILLIAM NELSON

R E NIGHTINGALE

I M RUSIN

R JEFF SERNE

R E WESTERMAN

I H WESTSIK IR

PARSONS, BRINCKERHOFF, QUADE, \&

DOUGLAS INC

T C CHEN

T R KUESEL

MARK E STEINER

PENBERTHY ELECTROMELT INTER NATIONAL INC

LARRY PENBERTHY

PENNSYLVANIA GOVERNORS ENERGY COUNCIL

HERBERT JACOBS

PENNSYLVANIA STATE UNIVERSITY

MICHAEL GRUTZECK

WILLIAM A JESTER

WILIIAM B WHITE

PERRY COUNTY SCHOOIS MANIEL A COCHRAN

PHYSIKALISCH-TECHNISCHE BUNDESANSTALT PETER BREN NECKE

POINT BEACH NUCLEAR POWER PLANT GLENN A REED

PORTLAND GENERAL ELECTRIC I W LENTSCH

POWER AUTHORITY OF THE STATE OF NEW YORK

MYRON M KACZMARSKY

POWER REACTOR AND NUCLEAR FUEL

DEVELOPMENT CORPORATION

PRESQUE ISLE COURTHOUSE

PUBLIC SERVICE INDIANA ROBERT S WEGENG

QUADREX CORP FRANCIS I KENESHEA

RADIAN CORP BARBARA MAXEY

RE/SPEC INC PALLF GNIRK

RENSSELAER POLYTECHNIC INSTITUTE JAMES WU

RIDIHALGH, FGGERS \& ASSOCIATES INC PHILIP E EGCERS

RIO ALGOM CORP

DUANE MATLOCK

RISO NATIONAL LABORATORY

LARS CARLSEN 
ROCKWELL HANFORD OPERATIONS

HARRY BABAD

G S BARNEY

$R$ A DEIL

$R$ I GIMERA

KARL M LA RUE

MICHAEL I SMITH

K THIRLMALAI

DAVE A TURNER

ROCKWELL INTERNATIONAL

$K \vee$ GILBERT

ROCKWEIL INTERNATIONAL ENERGY

SYSTEMS GROUP

HARRY PEARLMAN

LAWRENCE J SMITH

ROGERS \& ASSOCIATES ENGINEERING CORP

ARTHUR SUTHERL.AND

S.E. LOGAN \& ASSOCIATES INC

STANLEYE LOGAN

SAN DIEGO GAS \& ELECTRIC COMPANY LOUIS BERNATH

SAN JOSE STATE UNIVERSITY SCHOOL OF

ENGINEERING

$R$ N ANDERSON

SANDIA NATIONAL LABORATORIES

G C ALLEN

THOMAS O HUNTER

I KEITH JOHNSTONE

O E JONES

R W IYNCH

MARTINA MOLECKE

E I NOWAK

RICHARD E PEPPINC

G F RUDOLFO

ALLAN R SAITLER

LEOW SCULLY

A W SNYDER

A E STEPHENSON

DANIEL M TALBERT

WENDELL D WEART

WIPP CENTRAL FILES

SAVANNAH RIVER LABORATORY

E I HENNELLY

CAROL JANTZEN

WILLIAM R MCDONELL

$S W$ OREAR SR

JOHN A STONE

$S \vee$ TOPP

SCIAKY BROTHERS

JOHN C JASPER

SCIENCE APPLICATIONS INC

JEFFREY ARBITAL

RALPH FULLWOOD

IAMESE HAMMELMAN

RONALD HOFMANN

I ROBERT LARIVIERE

DAVID H LESTER

PETER E MCGRATH

JOHNE MOSIER

ROBERT A YODER

SCIENTISTS INSTITUTE FOR PUBLIC

INFORMATION

TERRY R LASH

SENECA COUNTY PLANNING BOARD

SHIMIZU CONSTRUCTION COMPANY LTD IUNJI TAKAGI

SIERRA CLUB

EDNA ZEAVIN

SIERRA CLUB - MISSISSIPPI CHAPTER

SIERRA GEOPHYSICS INC

STEPHEN L GILLETT
SNAKE RIVER ALLIANCE

TIM MCNEIL

SOUTH CAROLINA GEOLOGICAL SURVEY

NORMANK OLSON

SOUTH DAKOIA GEOLOGICAL SURVEY RICHARD BRETZ

SOUTH DAKOTA OFFICE OF ENERGY POLICY STEVEN M WEGMAN

SOUTHWEST RESEARCH AND INFORMATION CENTER

DON HANCOCK

SI \& E TECHNICAL SERVICES INC

STANLEYM KLAINER

ST BONAVENTURE UNIVERSITY

CARL J TWAROG

ST MARTIN HIGH SCHOOL RAYMOND I WERTHNER

SIANFORD UNIVERSITY

KONRAD B KRAUSKOPF

GEORGE A PARKS

IRWIN REMSON

STEADMAN \& HECTOR, P.A. ALICE G HECTOR

STEARNS-ROGER SERVICES INC VERYL ESCHEN

SIONE \& WEBSTER ENGINEERING CORP PATRICIA ANN OCONNELL

J PECK

ARLENE C POST

STUDSVIK ENERGITEKNIK AB ROLF SJOBLOM

SWANSON ENVIRONMENTAL INC PETER G COLLINS

SWISS FEDERAL OFFICE OF ENERGY $U$ NIEDERER

SYRACUSE UNIVERSITY WALTER MEYER

SYSTEM DEVELOPMENT CORP RHONNIE L SMITH

SYSIEMS SCIENCE AND SOFTWARE PETER LAGUS

T.M. GATES INC TODDM CATES

TECHNICAL INFORMATION PROJECT DONALD PAY

TECHNICAL RESEARCH CENTRE OF FINLAND OLLI I HEINONEN

SILJA RUMMUKAINEN

KARI SAARI

SEPPO VUORI

TEKNEKRON RESEARCH INC ANTHONYF MOSCATI

TELEDYNE PIPE TOBY A MAPLES

TENNESSEE DEPT OF PUBLIC HEALTH BILL GRAHAM

TEXAS A \& M UNIVERSITY ROY W HANN JR

TEXAS BUREAU OF RADIATION CONTROL DONALDG ANDERSON

TEXAS DEPT OF HEALTH DAVID K LACKER

TEXAS ENERGY \& NATURAL RESOURCES

ADVISORY COUNCIL TERRY BARRON CAROL KINC

TEXAS HOUSE OF REPRESENTATIVES PETE LANEY

THE ANAL YTIC SCIENCES CORP JOHN W BARTLETT CHARLES M KOPLIK I $W$ VOSS
THE JACKSON CLARION-LEDGER MARK SCHLEIFSTEIN

IIOGA COUNIY PLANNING BOARD PATRICK I SMYTH

TRINITY EPISCOPAL CHURCH BENIAMIN F BELL

TRW INC

PETER ALEXANDER

TUN ISMAIL ATOMIC RESEARCH CENTRE PUSPATI LIBRARY

U.H.D.E. FRANK STEINBRUNN

U.S. ARMY CORPS OF ENGINEERS ALAN BUCK

U.S. BUREAU OF LAND MANAGEMENT LYNN IACKSON EDWARD R SCHERICK

U.S. BUREAU OF MINES GEORGE E NIEWIADOMSKI

U.S. DEPT OF ENERGY

$R$ COOPERSTEIN

$S$ H GREENLEIGH

U.S. DEPT OF ENERGY - ALBUQUERQUE

OPERATIONS OFFICE

R LOWERY

JOSEPH M MCGOUGH

DORNER T SCHUELER

U.S. DEPT OF ENERGY - CHICAGO

OPERATIONS OFFICE

PUBLIC READING ROOM

$R$ SELBY

U.S. DEPT OF ENERGY - DALLAS SUPPORT OFFICE

CURTISE CARLSON IR

U.S. DEPT OF ENERGY - DIVISION OF WASTE REPOSITORY DEPIOYMENT

J W BENNETI

C R COOLEY (2)

WARREN EISTER

CYRUS KIINGSBERG

THOMAS P LONGO

RALPH STEIN

U.S. DEPT OF ENERGY - HEADQUARTERS

PUBLIC READING ROOM

U.S. DEPT OF ENERGY - IDAHO OPERATIONS OFFICE

JAMES F LEONARD

PUBLIC READING ROOM

J H SAKO

U.S. DEPT OF ENERGY - MATERIALS SCIENCE DIVISION

R I GOTTSCHALL

U.S. DEPT OF ENERGY - NEVADA OPERATIONS OFFICE

$M$ P KUNICH

PUBLIC READING ROOM

U.S. DEPI OF ENERGY - NWIS PROGRAM OFFICE

T BAILLIEUL

$M$ BLANCHARD

L A CASEY

R LAHOTI

L K MCCLAIN

I O NEFF

MARJORIE POPOVICH

$K K$ WU

R C WUNDERLICH

U.S. DEPT OF ENERGY - OAK RIDGE

OPERATIONS OFFICE

PUBLIC READING ROOM 
U.S. DEPT OF ENERGY - OFFICE OF NUCLEAR FUEL CYCLE O P GORMLEY

U.S. DEPT OF ENERGY - OFFICE OF PROJECT AND FACILITIES MANAGEMENT D L HARTMAN

U.S. DEPT OF ENERGY - OFFICE OF WASTE ISOLATION

JOSEPH A LEARY

IANIE SHAHEEN

U.S. DEPT OF ENERGY - OFFICE OF WASTE PRODUCTS

G K OERTEL

U.S. DEPT OF ENERGY - RICHLAND

OPERATIONS OFFICE

O L OLSON

PUBLIC READING ROOM

D I SQUIRES

U.S. DEPT OF ENERGY - SAN FRANCISCO

OPERATIONS OFFICE

ENERGY RESOURCES CENTER

LEN LANNI

PUBLIC READING ROOM

U.S. DEPT OF ENERGY - SAVANNAH RIVER OPERATIONS OFFICE REGINA T HARRIS

T B HINDMAN

U.S. DEPT OF ENERGY - TECHNICAL INFORMATION CENIER (27)

U.S. DEPT OF ENERGY - WIPP PROGRAM LAWRENCE H HARMON

U.S. DEPT OF LABOR KELVIN K WU

U.S. ENVIRONMENTAL PROTECIION AGENCY DIVISION OF CRITERIA \& STANDARDS DONALD HUNTER JAMES NEIHEISEL

U.S. GEOLOGICAL SURVEY - COLUMBUS A M LASALA JR

U.S. GEOLOGICAL SURVEY - DENVER RICHARD WADDELL ROBERT A ZIELINSKI

U.S. GEOLOGICAL SURVEY - MENLO PARK JOHN BREDEHOEFT

I BYERLEE

JACOB RUBIN

U.S. GEOLOGICAL SURVEY - RESTON

I MINC CHOU

IOHN ROBERTSON

EUGENE H ROSEBOOM $J R$

PETER R STEVENS

DAVID B STEWART

U.S. HOUSE SUBCOMMITTEE ON ENERGY

AND THE ENVIRONMENT

MORRIS K UDALL

U.S. NUCLEAR REGULATORY COMMISSION

R BOYLE

ENRICOF CONTI

MICHAEL C CULLINGFORD

I J DAVIS

PAUL F GOLDBERG

HIGH-LEVEL WASTE LICENSING BRANCH

HIGH-LEVEL WASTE TECHNICAL

LIBRARY

JOHN B MARTIN (3)

JOHN C MCKINLEY

HUBERT MILLER

EDWARD OCONNELL

$R$ JOHN STARMER

EVERETT A WICK
U.S. SENATE COMMITIEE ON ENERGY AND NATURAL RESOURCES

WILLIS D SMITH

UHDE GMBH

OLINGER

UNC NUCLEAR INDUSTRIES

ED POWERS

UNION CARBIDE CORP DENNIS J FENNELLY

UNION OF CONCERNED SCIENIISTS MICHAEL FADEN

UNITED KINGDOM DEPT OF THE

ENVIRONMENT

F S FEATES

RADIOACTIVE WASTE MANAGEMENT DIVISION

UNITED STATES GYPSUM COMPANY $T$ L ROSENSTIEL

UNIVERSITY OF ALABAMA AT BIRMINGHAM J WALTER MASON

UNIVERSITY OF ALBERTA

F W SCHWARTL

UNIVERSITY OF ARIZONA

IAAK DAEMEN

JAMESC MCCRAY

ROY G POST

UNIVERSITY OF CALIFORNIA AT BERKELEY

NEVILLEG $W$ COOK

THOMASH PIGFORD

UNIVERSITY OF CALIFORNIA AT LOS ANGELES D OKRENT

UNIVERSITY OF CALIFORNIA AT RIVERSIDE LEWIS COHEN

DON STILRMAN

UNIVERSITY OF CALIFORNIA AT SAN DIEGO RICHARD I WILLIS

UNIVERSITY OF DELAWARE

FRANK A KULACKI

UNIVERSITY OF FLORIDA

DAVIDE CLARK

DOLORES C JENKINS

UNIVERSITY OF HAWAII AT MANOA DAVID EPP

UNIVERSITY OF ILLINOIS AT URBANA -

CHAMPAIGN

ALBERT I MACHIELS

MAGDI RAGHEB

UNIVERSITY OF LOWELL JAMES R SHEFF

UNIVERSITY OF LULEA IAN NILSSON

UNIVERSITY OF MARYLAND MARVIN ROUSH

UNIVERSITY OF MINNESOTA

$$
\text { J K TYLKO }
$$

UNIVERSITY OF MISSISSIPPI GEORGE D BRUNTON

UNIVERSITY OF MISSOURI AT KANSAS CITY EDWIN D GOEBEL

UNIVERSITY OF MISSOURI AT ROLLA

ARVIND KUMAR

NICK TSOULFANIDIS

UNIVERSITY OF MODERA M ANTONINI

UNIVERSITY OF NEVADA AT RENO BECKY WEIMER

UNIVERSITY OF NEW MEXICO DOUGLAS G BROOKINS

UNIVERSITY OF OKLAHOMA DANIEL T BOATRIGHT
UNIVERSITY OF PITTSBURGH

$8 \perp$ COHEN

UNIVERSITY OF RHODE ISLAND

EDWARD P LAINE

UNIVERSITY OF SOUTHERN MISSISSIPPI

CHARLES R BRENT

JAMES W PINSON

GARY L WILDMAN

UNIVERSITY OF TENNESSEE AT KNOXVILLE I B FUSSELL

UNIVERSITY OF TEXAS AT AUSTIN JOE D LEDBETTER

UNIVERSITY OF TEXAS AT SAN ANTONIO DONALD R LEWIS

UNIVERSITY OF TOKYO RYOMEI KIYOSE

UNIVERSITY OF UTAH MEDICAL CENTER JAMES A SORENSON

UNIVERSITY OF UTAH RESEARCH INSTITUTE LIBRARY

UNIVERSITY OF WASHINGTON

DAVID BODANSKY

$M$ A ROBKIN

UNIVERSITY OF WESTERN ONTARIO

WILLIAMS FYLE

$P$ W M JACOBS

UNIVERSITY OF WISCONSIN

B C HAIMSON

UNIVERSIIY OF WISCONSIN AT MILWAUKEE HOWARD PINCUS

UTAH BUREAU OF RADIATION CONTROL DARRELL M WARREN

UTAH GEOLOGICAL AND MINERAL SURVEY MAGE YONETANI

UTAH SOUTHEASTERN DISTRICT HEALTH

DEPARTMENT ROBERT L FURLOW

UTILITY DATA INSTITUTE FRED YOST

VANDERBILT UNIVERSITY FRANK L PARKER

VERMONT AGENCY OF ENVIRONMENTAL CONSERVATION CHARLES A RATTE

VERMONT STATE NUCLEAR ADVISORY PANEL VIRGINIA CALLAN

VIRGINIA DEPT OF HEALTH ROBERT G WICKLINE

VIRGINIA DIVISION OF MINERAL RESOURCES ROBERT C MILICI

VIRGINIA MILITARY INSTITUTE HENRY D SCHREIBER

VIRGINIA POLYTECHNIC INSTITUTE AND

STATE UNIVERSITY WALTER HIBBARD

WASHINGTON DEPT OF SOCIAL AND HEALTH SERVICES

T STRONG

WASHINGTON HOUSE OF REPRESENTATIVES RAYISAACSON

WATTLAB

BOB E WATT

WAYNE STATE UNIVERSITY JAMES A WOODYARD

WBAI-FM WARREN LIEBOLD

WEST DADE REGIONAL LIBRARY LOURDES BLANCO LOPEZ

WEST VALLEY NUCLEAR SERVICES COMPANY INC

RICHARD M WINAR 
WEST VIRGINIA GEOLOGICAL AND ECONOMIC SURVEY ROBERT B ERWIN

WESIINGHOUSE ELECIRIC CORP GEORGE $\vee$ B HALL CAROL A KIZIS GEORCE P SABOL I R SCHORNHORST WESTINGHOUSE WIPP PROJECT WESTINGHOUSE ELECTRIC CORPORATION
WISCONSIN DEPT OF NATURAL RESOURCES DUWAYNE F GEBKEN

WISCONSIN DIVISION OF SIATE ENERGY ROBERT HALSTEAD WISCONSIN GEOLOGICAL AND NATURAL HISTURY SURVEY

MICHAEL G MUDREY IR MEREDITHE OSTROM

WISCONSIN PUBLIC SERVICE CORP

PAUL WOZNIAK
WOODWARD-CLYDE CONSULTANTS ASHOK PATWARDHAN WESTERN REGION LIBRARY WP-SYSTEM AB IVAR SAGEFORS WYOMING GEOLOGICAL SURVEY DANIEL N MILLER

YALE UNIVERSITY BRIAN SKINNER 